\title{
Competitive Intelligence Information and Innovation Performance of IRAP Funded Companies
}

\author{
by \\ Stoyan Tanev \\ A thesis submitted to the Faculty of Graduate Studies and Research \\ in partial fulfillment of the requirements for the degree of \\ Master of Engineering in Telecommunications Technology Management \\ Department of Systems and Computer Engineering \\ Carleton University \\ Ottawa, Canada, K1S 5B6 \\ December, 2004 \\ (C) Copyright 2004 Stoyan Tanev
}




$\begin{array}{ll}\begin{array}{l}\text { Library and } \\ \text { Archives Canada }\end{array} & \begin{array}{l}\text { Bibliothèque et } \\ \text { Archives Canada }\end{array} \\ \begin{array}{l}\text { Published Heritage } \\ \text { Branch }\end{array} & \begin{array}{l}\text { Direction du } \\ \text { Patrimoine de l'édition }\end{array} \\ \begin{array}{l}\text { 395 Wellington Street } \\ \text { Ottawa ON K1A ON4 } \\ \text { Canada }\end{array} & \begin{array}{l}\text { 395, rue Wellington } \\ \text { Ottawa ON K1A ON4 } \\ \text { Canada }\end{array}\end{array}$

Your file Votre référence ISBN: 0-494-00770-2

Our file Notre référence

ISBN: 0-494-00770-2

NOTICE:

The author has granted a nonexclusive license allowing Library and Archives Canada to reproduce, publish, archive, preserve, conserve, communicate to the public by telecommunication or on the Internet, loan, distribute and sell theses worldwide, for commercial or noncommercial purposes, in microform, paper, electronic and/or any other formats.

The author retains copyright ownership and moral rights in this thesis. Neither the thesis nor substantial extracts from it may be printed or otherwise reproduced without the author's permission.
AVIS:

L'auteur a accordé une licence non exclusive permettant à la Bibliothèque et Archives Canada de reproduire, publier, archiver, sauvegarder, conserver, transmettre au public par télécommunication ou par l'Internet, prêter, distribuer et vendre des thèses partout dans le monde, à des fins commerciales ou autres, sur support microforme, papier, électronique et/ou autres formats.

L'auteur conserve la propriété du droit d'auteur et des droits moraux qui protège cette thèse. $\mathrm{Ni}$ la thèse ni des extraits substantiels de celle-ci ne doivent être imprimés ou autrement reproduits sans son autorisation.
In compliance with the Canadian

Privacy Act some supporting forms may have been removed from this thesis.

While these forms may be included in the document page count, their removal does not represent any loss of content from the thesis.
Conformément à la loi canadienne sur la protection de la vie privée, quelques formulaires secondaires ont été enlevés de cette thèse.

Bien que ces formulaires aient inclus dans la pagination, il n'y aura aucun contenu manquant. 


\section{ABSTRACT}

This research examines how (i) company type and (ii) the intelligence information that small companies use to make decisions about innovation, affect their innovation performance. This research is exploratory and contributes to efforts of National Research Council Canada's Industrial Research Assistance Program (IRAP) to build a national competitive intelligence capability. The results obtained from examining data for 45 small new technology-based companies, specialized suppliers, and service companies suggest that: (i) the total number of intelligence information topics and the number of competitor related topics that IRAP funded companies use to make decisions about innovation are not related to the companies' innovation performance; (ii) the number of industry-related topics is positively related to specialized suppliers' new process innovation performance; (iii) the number of customer-related topics is positively related to new technology-based companies' new process innovation performance, and (iv) the number of company-related topics is positively related to new technology-based companies' new service innovation performance. 


\section{ACKNOWLEDGEMENTS}

I am deeply grateful to my supervisor Professor Tony Bailetti for his dedication, collaboration and tireless guidance in the various stages of preparing the thesis.

I would like to thank Professor John Callahan for his support and ideas for improvement of this research study.

The research study was completed in close collaboration between the Telecommunication Technology Management Program of the System and Computer Engineering Department at Carleton University, the Industrial Research Assistance Program at the National Research Council, the Canada Institute for Scientific and Technical Information and Vitesse Re-Skilling Canada. I would like to express my personal gratefulness to: Peter Cashmore, Director, IRAP, Ontario; Jean-Paul Plante, Coordinator, Competitive Technical Intelligence, CISTI; Olga Bosak, Innovation Networking Advisor, IRAP, Quebec; Denys Cooper, Senior Adviser - Technology, IRAP; Michel Mirota, ITA, IRAP, Quebec; Paul Tulonen, ITA, IRAP, Ontario; Arvind Chhatbar, President, Vitesse ReSkilling Canada.

I would like to thank my wife Maia and my son George for their love, understanding and continuous support. 


\section{TABLE OF CONTENTS}

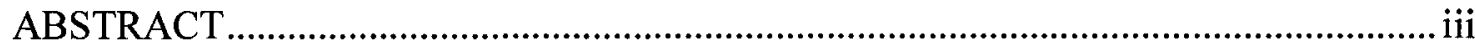

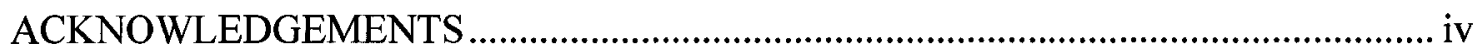

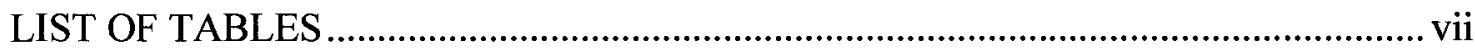

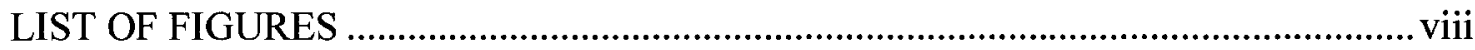

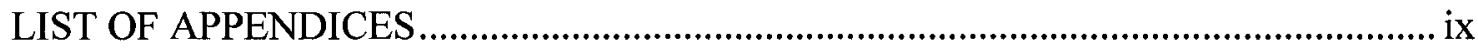

1 INTRODUCTION

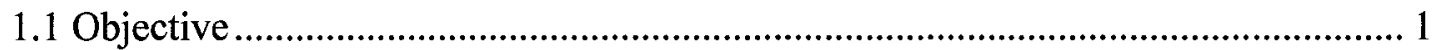

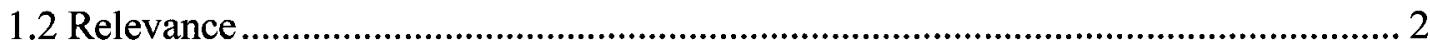

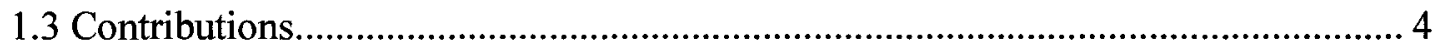

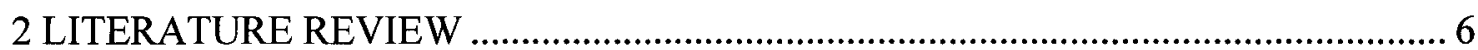

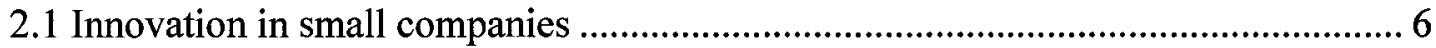

2.1.1 Dimensions of innovation and stages of innovation process ........................... 6

2.1.2 Technological innovation in small companies................................................. 9

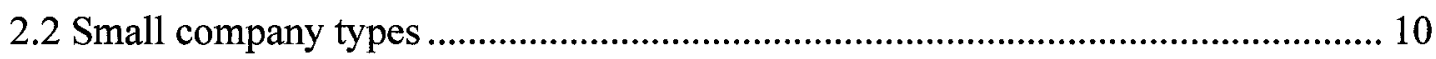

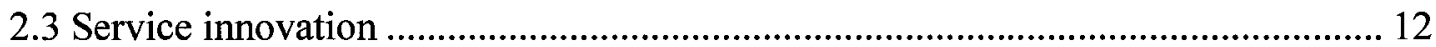

2.4 Determinants of innovation performance ...................................................... 14

2.5 Competitive intelligence in small companies .................................................... 17

2.5.1 Competitive intelligence ....................................................................... 17

2.5.2 Intelligence information and innovation performance................................ 20

2.5.3 Key intelligence topics......................................................................... 21

2.5.4 Competitor targeting framework.......................................................... 22

2.5.5 Company types, intelligence information and innovation ........................... 24

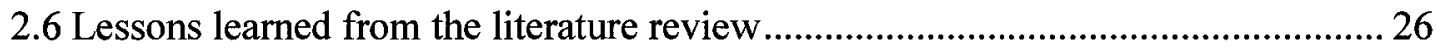

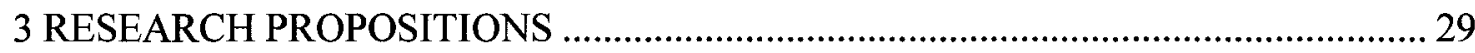

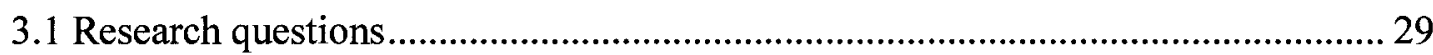

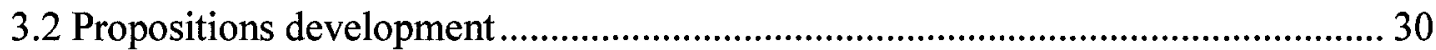

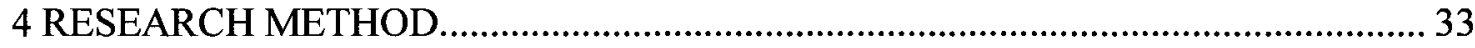

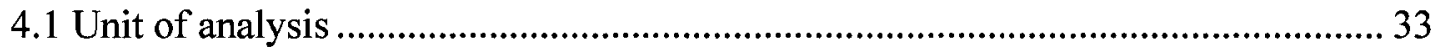

4.2 Sample

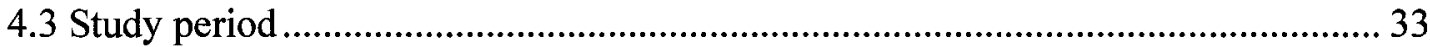

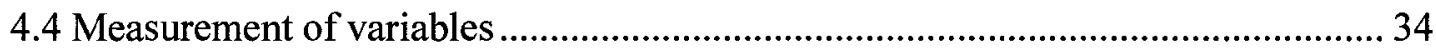

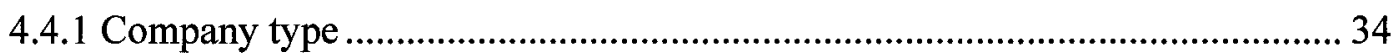

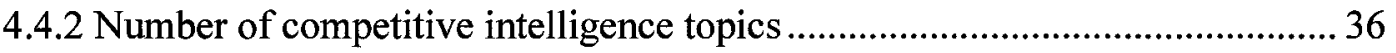

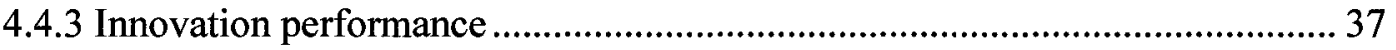




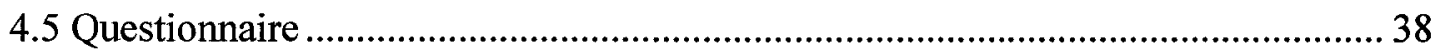

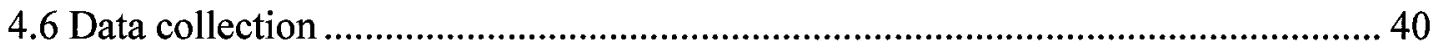

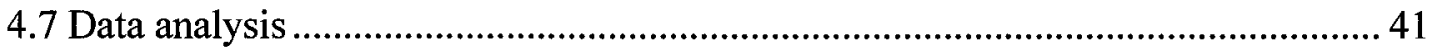

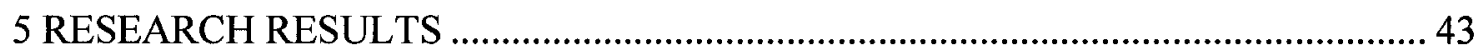

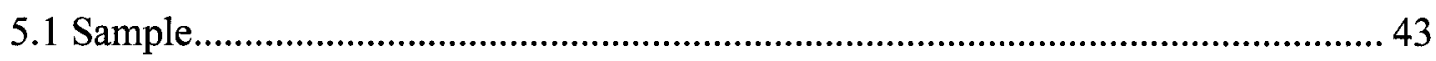

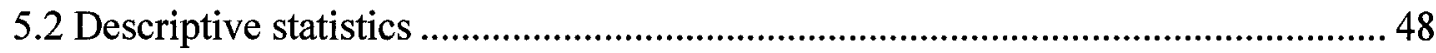

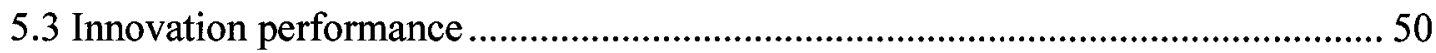

5.4 Innovation performance and number of intelligence information topics................ 55

5.4.1 Results for the full sample of 45 companies ................................................ 55

5.4.2 Results for the new technology-based sub-sample sample......................... 57

5.4.3 Results for the specialized supplier sub-sample ...........................................6 60

5.4.4 Results for the service company sub-sample ................................................6. 62

5.4.5 Summary of stepwise regression results ....................................................6 63

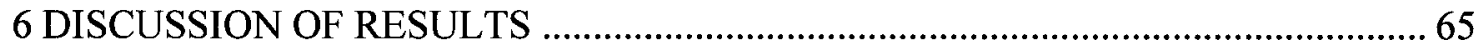

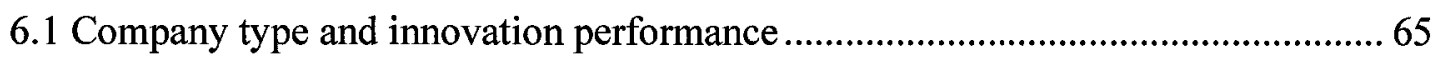

6.2 Innovation performance and intelligence information topics .................................67

7 CONCLUSIONS, LIMITATIONS AND SUGGESTIONS

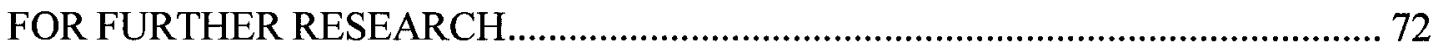

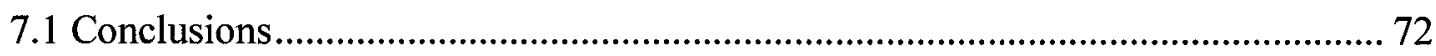

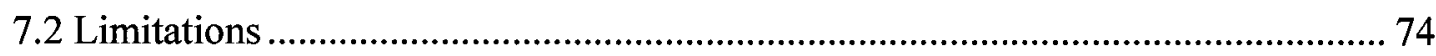

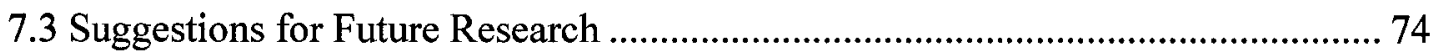

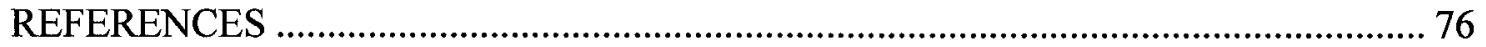




\section{LIST OF TABLES}

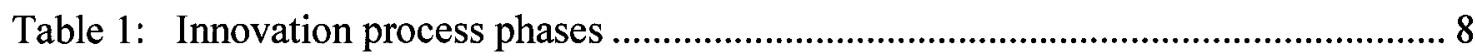

Table 2: Misleading assertions about innovation in small firms .................................. 10

Table 3: Frequency distribution of companies in the sample by company type............. 43

Table 4: Frequency distribution of companies in the sample by number of employees. 44

Table 5: Distribution of companies per year of incorporation...................................... 46

Table 6: Descriptive statistics of the variables used in this research............................. 48

Table 7: Descriptive statistics of the normalized innovation performance variables .... 49

Table 8: Descriptive statistics of innovation performance means by company type...... 50

Table 9: ANOVA results for differences in innovation performance means ................. 51

Table 10: Results of performing the Welch test ........................................................... 52

Table 11: Bonferroni multiple comparison test results................................................... 53

Table 12: Games-Howell multiple comparison test results ........................................... 54

Table 13: Regression results using number of new processes to the power of (1/3) as the dependent variable and the 45 company sample .................................56

Table 14: Results of stepwise linear regression with number of new processes to the power of (1/3) as dependent variable using the sub-sample comprised of new technology-based companies ............................................................... 57

Table 15. Results of stepwise linear regression with number of new services to the power of $(1 / 2)$ as dependent variable using the sub-sample comprised of new technology-based companies ............................................................. 59

Table 16: Results of performing stepwise linear regression with number of new processes to the power of $(1 / 3)$ as the dependent variable using the sub-sample comprised of specialized suppliers

Table 17: Results of performing stepwise linear regression with number of patents filed to the power of (1/5) as dependent variable using the sub-sample comprised of service companies

Table 18: Results obtained by using stepwise regressions to examine the relationship between innovation performance and number of information topics used to make decisions about innovation 


\section{LIST OF FIGURES}

Figure 1: Dimensions of innovation space............................................................... 7

Figure 2: Competitive Intelligence process phases........................................................... 19

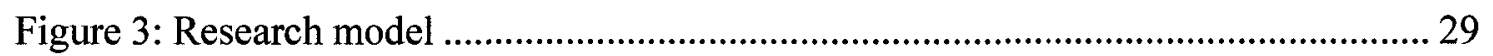

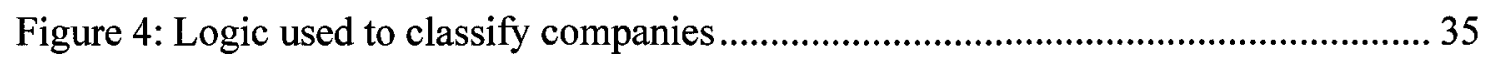

Figure 5: Histogram of the number of company employees per company type................ 45

Figure 6: Histograms of the years of incorporation for each company type ................... 47

viii 


\section{LIST OF APPENDICES}

Appendix A. The Industrial Research Assistance Program................................................ 88

Appendix B. Definitions of new product, new process and new service ......................... 91

Appendix C. Intelligence information topics.................................................................. 94

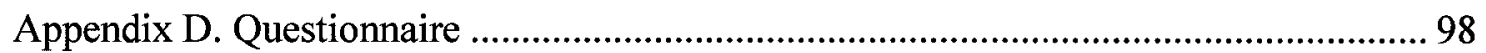

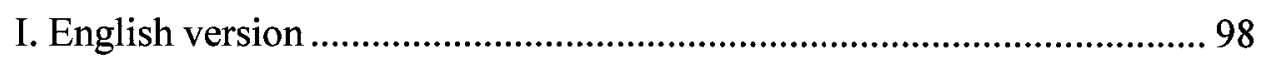

II. French version ............................................................................... 106 


\section{INTRODUCTION}

\subsection{Objective}

The objective of this thesis is to examine how company type and the number of intelligence information topics that small companies use to make new product, process, service and patent decisions affect the innovation performance of the Canadian companies funded by the Industrial Research Assistance Program (IRAP). ${ }^{1}$

This research is anchored around three questions:

- Does company type affect innovation performance?

- Does the number of intelligence information topics used by companies to make new product, process, service and patent decisions affect their innovation?

- Does company type affect the relationship between the number of intelligence information topics used to make decisions and innovation performance?

The IRAP funds Canadian companies with less than 500 employees. ${ }^{2}$ These companies can be classified by using a Pavitt-like taxonomy (Pavitt, 1984; Pavitt, Robson \& Townsend, 1989; Tidd, Bessant \& Pavitt, 2001) into four types: new technology-based

\footnotetext{
${ }^{1}$ The National Research Council's Industrial Research Assistance Program (IRAP) is Canada's premier innovation assistance program for small and medium-sized Canadian companies. The IRAP is regarded worldwide as one of the best programs of its kind.

${ }^{2}$ The IRAP offers advisory services as well as potential access to financial assistance to companies that i) are incorporated and profit-oriented, ii) have less than 500 employees and iii) desire to enhance their innovation capability. A more detailed description of IRAP's services is given in Appendix A.
} 
companies, specialized suppliers, supplier technology-dominated companies, and service companies.

Based on definitions in the OSLO manual ${ }^{3}$ (Organization for Economic Co-operation and Development, 1997), the following variables are used to measure innovation performance:

- the number of technologically new products introduced in the last three years

- the number of technologically new processes introduced in the last three years

- the number of technologically new services introduced in the last three years

- the number of patents filed in the last three years.

\subsection{Relevance}

This research is relevant for at least two reasons. First, one of IRAP's strategic initiatives is to develop competitive intelligence (CI) capability to support innovation in small Canadian companies (Industrial Research Assistance Program, 2002). To prioritize IRAP's investments when developing this capability requires a better understanding of the relationship between competitive intelligence and innovation performance.

\footnotetext{
${ }^{3}$ The OSLO manual is the foremost international source of guidelines for the collection and use of data on industrial innovation activities. It was developed by Organization for Economic Co-operation and Development (OECD).
} 
The second reason that this research is relevant is that there is little known about the relationship between competitive information and innovation performance for small technology driven companies.

\section{National competitive intelligence capability}

To innovate, companies need $\mathrm{CI}$ information. The IRAP facilitates the access to $\mathrm{CI}$ information and promotes the benefits of using competitive intelligence. The IRAP has identified the efficient management of CI information as one of the challenges that small Canadian companies must address. The development of a national CI capacity necessitates a better understanding of the relationship between competitive intelligence information and innovation performance for IRAP funded companies.

\section{Intelligence information and innovation}

To be competitive, small companies need to use a broad range of CI information (Ali \& Swiercz, 1991; Verhoeven, 1988; Reid, 1984; Seringhaus, 1987; Christensen, 1991). CI practices lay the foundation of both firm's innovation processes and competitiveness (Tidd, Bessant \& Pavitt, 2001).

While the relationship between intelligence information and innovation performance of small companies is deemed to be very important, it is not well researched yet (Julien, Toulouse, Ramangalahy, Morin \& Lachance, 1998; Brouard, 2002; Audet, 2003; Savioz, 2004). Studies on the relationship between intelligence information and innovation performance focus on the analysis of information sources and not on the specific information topics that are used (Souitaris, 2001, 2002; Freel, 2003; Bommer \& Jalais, 2004). The focus on information sources sometimes leads to controversial findings in the 
published research studies. For example, Souitaris $(2001,2002)$ finds that cooperation and communications between science-based Greek companies and external organizations are positively associated with innovation performance. External organizations are deemed to be important sources of external information. On the other hand, Freel (2003) finds that, in the case of small innovative companies, sources of intelligence information from external organizations are not necessary for successful innovation.

\subsection{Contributions}

This research makes two contributions.

First, the results of this study provide the IRAP with insights that can assist in the development of a national competitive intelligence capacity. The study

- demonstrates the need of a company taxonomy in the evaluation of innovation performance of IRAP's clients

- demonstrates the role of service innovation in both product and service companies

Second, this is the first study to examine the relationship between competitive intelligence information and innovation performance using a sample of small companies within IRAP's context.

The thesis is organized into seven chapters. Chapter 1 is the introduction. Chapter 2 provides a review of the literature and lessons learned from it. Chapters 3 and 4 describe the research propositions and research method used in the thesis. The results of the 
research are in Chapter 5. Chapter 6 provides a discussion of the results. Finally, Chapter 7 includes conclusions, limitations and suggestions for further research. 


\section{LITERATURE REVIEW}

This chapter is organized into six sections. The first section reviews innovation in small companies. In the second section, the literature on small company classifications is reviewed. The third section examines the literature on service innovation. The fourth section reviews the literature on determinants of innovation performance. The characteristics of competitive intelligence in large and in small companies are reviewed in the fifth section. Finally, the sixth section of this chapter presents the lessons learned from the literature review.

\subsection{Innovation in small companies}

\subsubsection{Dimensions of innovation and stages of innovation process}

Technological innovation can be thought of as having two dimensions: (i) what is changed and (ii) the perceived extent of the change (Tidd et al., 2001). Figure 1 illustrates the two dimensions of innovation as presented by Tidd et al. (2001, p. 8) 


\section{Figure 1: Dimensions of innovation space}

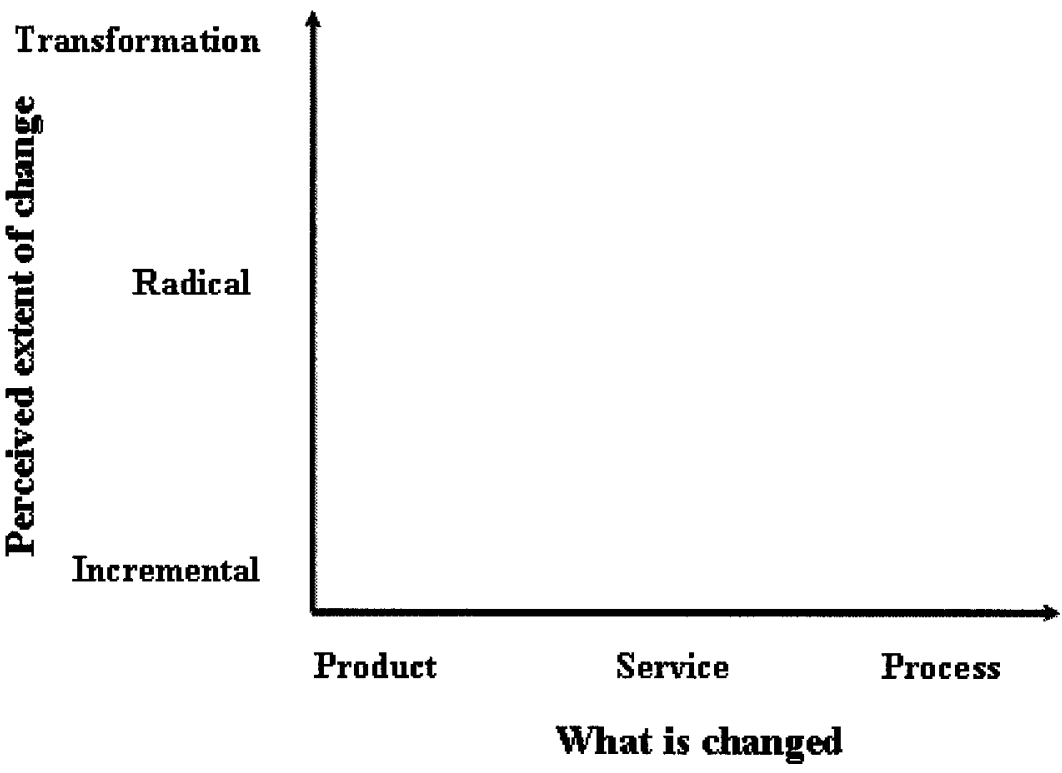

Source: Tidd et al., 2001, p. 8

Table 1 shows that the innovation process involves four phases. The first phase, Signal processing or Scanning, involves detecting signals in the environment about potential for change. The second phase, Strategy, involves deciding to which of these signals to respond. The third phase, Resourcing, involves combining knowledge available inside and outside the organization to offer solutions to problems. The fourth phase, Implementation, involves developing the technology and its internal and external market. 
Table 1: Innovation process phases

\begin{tabular}{|c|c|c|c|}
\hline Signal processing & Strategy & Resourcing & Implementation \\
\hline $\begin{array}{l}\text { Scan environment } \\
\text { for technological, } \\
\text { market, regulatory and } \\
\text { other signals. } \\
\text { Collect and filter out } \\
\text { signals from } \\
\text { background noise. } \\
\text { Scan forward in time. } \\
\text { Process signals into } \\
\text { relevant information for } \\
\text { decision-making. }\end{array}$ & $\begin{array}{l}\text { Analysis, choice, plan. } \\
\text { Assess signals in terms } \\
\text { of possibilities for } \\
\text { action. } \\
\text { Link with overall } \\
\text { business strategy. } \\
\text { Link with core } \\
\text { knowledge based } \\
\text { competencies. } \\
\text { Assess costs and } \\
\text { Agree and commit } \\
\text { resources. } \\
\text { options. }\end{array}$ & $\begin{array}{l}\text { Procure solutions which } \\
\text { realize strategic } \\
\text { decisions. } \\
\text { Invent in-house through } \\
\text { R\&D activity. } \\
\text { Use from existing R\&D. } \\
\text { Acquire via external } \\
\text { R\&D contact. } \\
\text { License or buy-in. } \\
\text { Technology transfer. }\end{array}$ & $\begin{array}{l}\text { Develop to maturity. } \\
\text { Parallel technical } \\
\text { development and } \\
\text { development of the } \\
\text { relevant market. } \\
\text { For product } \\
\text { development this is } \\
\text { external customer market. } \\
\text { For process } \\
\text { development this is } \\
\text { Launch and commission. } \\
\text { internal use market. } \\
\text { Both require "change } \\
\text { management". } \\
\text { After sales support. } \\
\text { ing }\end{array}$ \\
\hline
\end{tabular}

Source: Tidd et al., 2001, p. 53 


\subsubsection{Technological innovation in small companies}

Compared to large companies, small companies have similar objectives (Tidd et al., 2001). Small companies set out to develop and combine technological and other competences in order to deliver goods and services that satisfy customers better than alternatives. Small companies do not need the formal strategies that are used in large companies to ensure communication and coordination.

The technological weaknesses of small companies relative to large companies are three. First, small companies specialize in a narrow range of technologies. Second, smaller companies are unable to develop and manage complex systems. Third, small companies find it difficult to fund long-term risky programs.

Small companies are more innovative in certain sectors, such as machinery, instruments and software, while large companies are more innovative in other sectors such as chemicals, electronics and transport (Tidd et al., 2001).

Lack of research on innovation in small companies has lead to several misleading assertions. Table 2 provides examples of misleading assertions about innovation in small companies and what the evidence shows (Tidd et al., 2001). 
Table 2: Misleading assertions about innovation in small firms

\begin{tabular}{|l|l|}
\hline \multicolumn{1}{|c|}{ Misleading assertions } & \multicolumn{1}{c|}{ What the evidence shows } \\
"Small companies make most of the & $\begin{array}{l}\text { It depends on the product and the } \\
\text { technology. }\end{array}$ \\
\hline $\begin{array}{l}\text { "Small companies make few } \\
\text { innovations since they do so little } \\
\text { R\&D." }\end{array}$ & $\begin{array}{l}\text { They do lots of informal, part-time and } \\
\text { non-measured R\&D and innovate } \\
\text { accordingly. }\end{array}$ \\
\hline $\begin{array}{l}\text { "Small companies are much more } \\
\text { since they account for a higher share } \\
\text { of innovations than R\&D." }\end{array}$ & $\begin{array}{l}\text { Not if you include unmeasured, "part- } \\
\text { time" R\&D }\end{array}$ \\
\hline $\begin{array}{l}\text { "New small companies create a lot } \\
\text { of employment." }\end{array}$ & $\begin{array}{l}\text { They also lose a lot, since they have } \\
\text { high birth and death rates. }\end{array}$ \\
\hline
\end{tabular}

Source: Tidd et al., 2001, p. 82

\subsection{Small company types}

Despite more than three decades of empirical research designed to determine the characteristics of innovative companies and the factors associated with success or failure in innovation, there is still no precise prescription for successful innovation (Souitaris, 2002; Rothwell, 1992). Different researchers have tested similar potential innovation factors but discovered differing degrees of association with innovation rate (Wolfe, 1994; Souitaris, 1999). Three important sources of results inconsistency have been identified in the literature - the type of innovation, the industrial sector, and the size of the company (Mohr, 1969; Downs \& Mohr, 1976; Rothwell, 1974, 1977; Carrier, 1994; Lefebvre, 
Mason \& Lefebvre, 1997). In the 1980s, to explain the inconsistency of the results, some authors proposed the use of companies' classifications (Miller \& Friesen, 1984; Khan \& Manopichetwattana, 1989).

Small company classifications used in empirical research studies build on the company classification originally developed by Pavitt (1984). Pavitt's company taxonomy allows large amounts of complex information to be reduced to more convenient categories, which are easier to comprehend (Souitaris, 2002).

Pavitt's original classification included four company types: (i) Supplier technologydominated companies, (ii) Large scale producers, (iii) Specialized suppliers, and (iv) Science based-companies. Three dimensions were used to distinguish company types: the sources of technology that companies adopt, the uses of the technology that companies develop, and the methods used by successful innovators to appropriate the benefits of their activities. Tidd et al. (2001) extends Pavitt's original classification by adding a fifth company type - the "Information-intensive firms". The Informationintensive firms belong to service industries such as finance, retailing and software.

Based on Pavitt's original classification, Tidd et al. (2001,) proposed a small company that includes four company types: superstars, new technology-based companies, specialized suppliers and supplier technology-dominated companies. Superstars are large firms that have emerged from small ones through high rates of growth based on the exploitation of a major invention. The new technology based and supplier technology 
dominated companies are comprised of service and manufacturing companies.

Freel (2003) also uses Pavitt's (1984) original classification to study small and mediumsized firms' innovation. Freel (2003) uses three company types: (i) Supplier dominated firms, (ii) Production intensive firms, and (iii) Science based firms.

It is worth noting that mixing manufacturing and service companies in the analysis of small company innovation was shown to be (Hoffman et al., 1998) the source of significant biases in innovation research. Manufacturing and service company fundamentals, particularly in regards to the role of technology and its impact on company performance, are very different and require a careful differentiation (Hoffman et al., 1998, Sirilli et al., 1998).

\subsection{Service innovation}

Research studies on innovation performance have focused on manufacturing industries (Weerawardena et al., 2002). While innovation is recognized as important for national competitiveness and economic growth, services tend to be viewed as innovation laggards that make little or no contribution to either productivity or growth (Windrum \& Tomlinson, 1999). However, dependence on services is increasing (Weerawardena et al., 2002).

Service innovations enable companies to gain competitive advantage (Coyne, 1993; Easingwood \& Mahajan, 1989; Kaplan, 2000; Morris \& Westbrook, 1996). Only recently 
have researchers begun to address issues related to the wide broad of services that are offered (Weerawardena et al., 2002; Johne \& Storey, 1998). Furthermore, all existing studies focus predominantly on service innovation in large companies (Weerwardena, 2002; Kaplan, 2000; Evangelista, 2000; Windrum et al., 1999; Sirilli \& Evangelista, 1998).

Services differ from products in a number of key characteristics. Several researchers have stressed that the interaction with the customer in the service development process is an important factor that distinguishes new service from new product development (Johne et al., 1998). Extending this view, Edvardsson et al. (1996) argue that the customer is a "coproducer" of services. The literature dealing with new product development suggests that customers are an important source of idea generation. In the case of services, customers form an integral part of the new service development process.

Some other key characteristics of services can be summarized as follows (Sirilli et al., 1998):

- a stronger emphasis on immediate consumption

- $\quad$ services can make a crucial difference to a package of products: they are often a key factor for adapting broader product categories to specific customer needs.

- a high information-intangible content

The differences between service and product innovation reflect the need for a framework that will allow to examine service innovation as an integral part of the innovation strategy of a firm (Weerawardena et al., 2002). 


\subsection{Determinants of innovation performance}

The innovation performance of a given company can vary substantially depending on the innovation measure used (Tidd et al., 2001). Multiple innovation performance indicators can offer a better understanding of innovation performance, shedding light on the problem from different angles and overcoming the incompleteness of the individual measures (Saviotti \& Metcalfe, 1984; Hagedoorn \& Cloodt, 2003).

The measurement of innovation performance should equally include product, process and service types of innovation (Weerawardena et al., 2002). For example, in a recent study, Souitaris (2002) measured innovation performance by means of seven variables drawn from the OSLO Manual (Organization for Economic Co-operation and Development, 1997):

- the number of incrementally innovative products introduced in the last 3 years

- the number of radically innovative products introduced in the last 3 years

- the number of innovative manufacturing processes introduced in the last 3 years

- the percentage of current sales due to incrementally innovative products introduced in the last 3 years

- the percentage of current sales due to radically innovative products introduced in the last 3 years

- the expenditure on innovation in the last 3 years over current sales (including R\&D funding and capital expenditure on innovative manufacturing processes) 
- the number of patents acquired in the last 3 years

The definitions of technologically new products, new processes and new services are given in Appendix B.

Internal and external factors affect innovation (Souitaris, 2002). Exploiting external knowledge and information is a critical component of innovative activities (Cohen \& Levinthal, 1990). Collaborative linkages and networking improve the innovation potential of organizations (Achrol, 1997). External technology linkages are frequently employed strategic alternatives to internal $R \& D$ efforts in highly innovative companies (Rothwell, 1992). External linkages supplement the development of new products and processes of small companies, which tend to suffer a marked disadvantage in material and human resources required for technological innovation (Rothwell et al., 1989, 1991).

Souitaris (2001) studied explicitly the effect of external communication determinants of innovation. Firm-specific information was found to be positively associated with innovation and was obtained from customers, suppliers of raw materials, suppliers of machinery and equipment, and competitors. General information on market and technological trends was found to be positively associated with a high rate of innovation. The sources of this information were identified as public agencies and private consultants, distributors and partners, professional associations, scientific and trade journals, trade fairs, the Internet, and electronic patent and research databases. Souitaris (2001) also found a positive association between co-operation with external organizations 
and high innovation rate.

Souitaris (2002) validated the application of Pavitt's classification (Pavitt, 1984; Tidd et al., 2001) in the study of firms' innovation factors. Souitaris selected Pavitt's original classification because it produced company types with similar size, industrial sector and innovation type. The research question was whether the rate and the determinants of innovation of the highly innovative companies varied according to Pavitt's company types. Souitaris used a relatively large portfolio of 58 literature-derived and widely acknowledged factors associated with company innovativeness. The variables were categorized in four classes: contextual, strategy related, external communications, and organizational context variables (Souitaris, 2002).

Souitaris (2002) showed that the important determinants of innovation differ in the four classes of Pavitt's classification: determinants of innovation for supplier dominated companies are related to the competitive environment, strength of marketing, acquisition of external information, inclusion of technology plans in the business strategy, attitude towards risk and internal co-ordination; for scale-intensive companies, the important variables are related to the ability to finance innovation projects and with the education and experience of personnel; for innovative specialized suppliers, the important variables are related to the search for technology ideas and with the definition of the business strategy; for the science-based companies, important determinants of innovation include technology-related variables, education and experience of personnel, growth rate in profit and panel discussions with customers. Pavitt's original classification proved to be a useful tool for simplifying the problem of multi-dimensional moderation of innovation, 
which management scholars faced: firm's size, industrial sector and type of innovation can be reduced into a single, general dimension: the company type.

In the application of Pavitt's original company classification to small firms' innovation factors, Freel (2003) explored two essential issues: the degree of association between external linkages and company level innovative performance and the extent to which such linkages are clustered spatially. He found that $53 \%$ of science-based companies (i.e. those for which external knowledge and external interactive learning is considered particularly relevant), within the sample, recorded no external collaboration during the survey period. The study showed that external collaboration in innovative small companies was neither a necessary nor a sufficient condition for successful innovation. This latter finding was in accordance with other studies (Oerlemans, Meeus \& Boekema, 1998; Nelson, 2000) and showed that innovation was a process primarily built on internal capabilities but contradicted the finding of Souitaris (2002) about innovation factors in Greek companies.

\subsection{Competitive intelligence in small companies}

\subsubsection{Competitive intelligence}

Competitive intelligence (CI) can be defined as "actionable recommendations arising from a systematic process involving planning, gathering, analyzing, and disseminating information on the external environment for opportunities, or developments that have the potential to affect a company's or countries competitive situation" (Calof \& Skinner, 
1998; Calof, 2002). CI is also defined as "actionable information about the external business environment that could affect a company's competitive position" (Ashton \& Kalvans, 1997) or an "informational process whereby an organization listens to its environment to decide and to act in the pursuit of its objectives" (Brouard, 2002).

CI tracks the activity of direct and indirect competitors, customers, suppliers and partners in a range of fields: general business activity, business development, strategy and tactics in different sectors or new activities, market penetration, tangible and intangible needs evolution, patent registration, research activity, new technology development and others (Rouach \& Santi, 2001). It can be compared to a radar screen that spots new opportunities, helps avert disasters, and enables the company to observe its own evolution and environment.

The CI activities are usually organized in an intelligence process, the main phases of which are shown in Figure 2. The final goal of the CI process is the application of the CI results to strategic decisions and actions undertaken by the company based on the actionable intelligence information, as a response to changes in or new findings about its overall competitive environment. 
Figure 2: Competitive Intelligence process phases

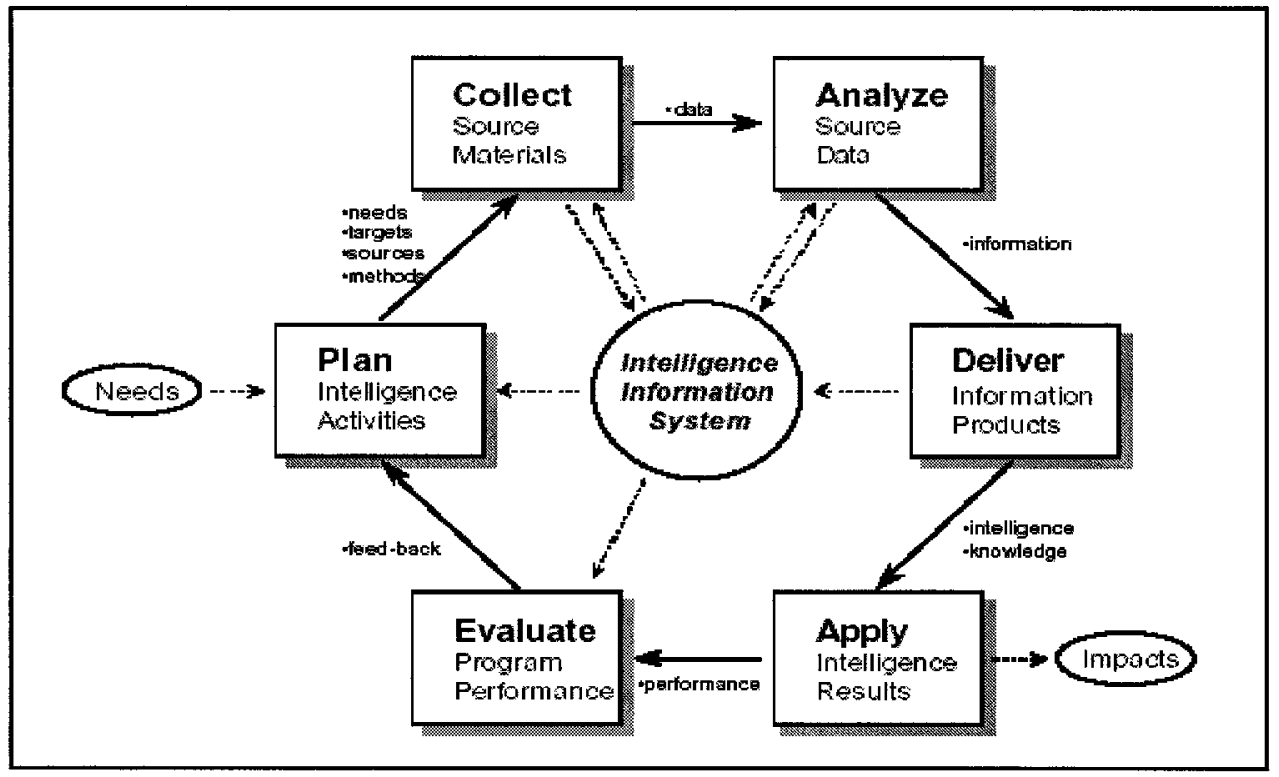

Source: Savioz (2004)

Most of the research on CI deals mainly with large companies, however, the importance of CI for small companies has been explicitly recognized (Broome, 2001; Savioz, 2004). It is recognized that small companies differ in their competitive behaviour from their large rivals in a specific industry (Chen \& Hambrick, 1995). Recent research on small businesses usually focuses on small high-tech start-ups (Cobbenhagen, 2000). In many of the technology-based company cases, the emphasis is on technical intelligence and its influence on new product development (Noori et al., 2001; Deszca, Munro \& Noori, 1999; Katila, 2002). The role of intelligence information for new process and service development is seriously understudied (Weerawardena, 2003). Some of the findings are controversial and do not help to understand whether small companies should or could practice intelligence activities, and if there is an obvious link between CI activities and innovation capacity and performance (Savioz, 2004). 


\subsubsection{Intelligence information and innovation performance}

CI activities provide actionable intelligence information that enables executive management's strategic decisions and actions aiming at enhancing the competitiveness and overall innovation performance of a firm (Ferrier, 2001). However, in spite of its long existence in certain countries, $\mathrm{CI}$ is not recognized as something to improve the innovation in, and competition of, Canadian ventures (Brouard, 2002; Calof \& Brouard, 2004).

Intelligence information practices of small companies (Julien et al., 1998) are based on their information management capabilities, measured empirically by the number and the relative importance of the different types of intelligence information used. The ability of a firm to master information and knowledge constitutes an essential factor in business success (Madhok, 1996; Lapointe, 1995; Porter, 1990). The ability of small businesses to perform well in both local and foreign markets is closely associated with their ability to acquire the necessary competitive information and knowledge. Information, and the ability to locate and exploit information, are the means by which businesses are able to identify new opportunities and export possibilities, and acquire new knowledge (Johanson \& Vahlne, 1993; Christensen, 1991).

The innovation strategy of a specific company can be a major component of its overall business strategy (Tidd et al., 2001). Research examining the firm's innovation and overall performance suggests that innovations lead to higher performance (LengnickHall, 1992; Lefebvre et al., 1993). The competitiveness of small businesses is generally 
based on a wide range of factors that support innovation and differentiation. These factors are related to small businesses' ability to master outside information (Namiki, 1988).

The link between particular intelligence information topics and the innovation performance of a firm is materialized through decisions about new products, processes, services and patents, and the specific actions undertaken based on these decisions (Savioz, 2004). Audet (2003) has pointed out that, although there is a perceived expectation of a positive association between the ability of small companies' managers to manage external and internal intelligence information, and the firm's performance, very few authors have dedicated efforts to study this association. Audet found that the innovation propensity of executive managers was a significant driver for enabling the intelligence information processing capability of high-tech, high performance small companies. However, no relationship was established between the scope and variety of the intelligence information used and the innovation performance of a small firm.

\subsubsection{Key intelligence topics}

Key Intelligence Topics (KITs) have traditionally dominated CI professional literature as the preeminent list of priorities and factors that define the scope of competitive intelligence activities (Herring, 1999, 2002; Johnson, 2002). The areas covered by a set of KITs are very diverse and attempt to include the complete competitive environment of the firm.

For example, Herring, (1999, 2002) developed a systematic KIT process for the 
identification of management's specific intelligence needs. Company's intelligence information needs were assigned to one of three functional categories: strategic decisions and actions - including the development of strategic plans and strategies; early-warning topics - including competitor initiatives, technological surprise, and governmental actions; and descriptions of the key players in the specific marketplace - including competitors, customers, suppliers, regulators, and potential partners.

Johnson (2002) suggested another set of KITs: current competitor activities and strategy monitoring, customer and vendor monitoring, operational/performance benchmarking, strategic probabilities and possible futures, product/service sales and marketing support, internal knowledge management, intellectual property exploitation/protection, M\&Aalliance-investment support, long-term market prospects, counter-intelligence and information security, legislative/regulatory impact on business issues, decision-support and consultative briefings. Johnson's list describes the CI priorities in order of levels of sophistication and relative importance to the average enterprise.

\subsubsection{Competitor targeting framework}

Recently, Gordon (2002) developed a competitor-targeting framework dealing with a very broad range of competitive intelligence information topics. The framework represents an integration of Porter's $(1980,1985)$ five-forces model and the customer relationship management (CRM) approach (Gordon, 1998). Gordon's framework is inherently linked to innovation and strategy formation. It was found to be the most appropriate for the purposes of our research. The framework builds on four individual 
assessments to arrive at a set of strategic issues that are critically important for competitor targeting: industry, customer, competitor and company.

Industry Assessment. It comprises an assessment of the future state of the firm's industry, the current state of the industry and the likely transition to the future state. This assessment concludes with the question: "What must any company do to be successful in the industry future state?" The answer to this question is based on the analysis of intelligence information topics listed in Appendix C (Gordon, 2002, p. 110).

Customer Assessment. Customer assessment considers the most important customers of a company and includes answers to the following questions: "Which customers should any company focus on in our own industry?", "Which customers can we best bond with, including the current customers identified by our CRM initiatives?", "What would any company need to do to win more or all of the business of the best customers in the industry?" The answers to the above questions are based on the analysis intelligence information topics listed in Appendix C (Gordon, 2002, p. 115).

Competitor Assessment. Competitor assessment is based on the answer to the questions: "What any company must do to be successful in the future state of the industry?", and "How are the various industry participants positioned to succeed?" The positioning is established by conducting an assessment of competitors' capabilities in relation to key success factors. The competitor assessment also comprises competitors' positioning with respect to the key customer success factors identified in the customer assessment. The goal is to establish the relative strengths and weaknesses for specific competitors in each account to determine which ones represent the main threats and opportunities for the 
firm. Ideally, competitors' profiles may be completed to describe the targeted competitors completely and gauge their strategies, strengths and weaknesses. Competitors' profiles provide answers to all of the above questions based on the analysis of competitive intelligence information topics listed in Appendix C (Gordon, 2002, p. 118).

Company Assessment. In order to enhance their ability to win customers from competitors, companies need a thoughtful consideration of the reasons for their own historical competitiveness, including their very reason for existence. Going forward, they need to establish the capabilities that will allow them to displace competitors. The intent of company assessment is to develop the above understanding by asking and answering questions such as those listed in Appendix C (Gordon, 2002, p. 124).

The approach suggested by Gordon (2002) is developed on an attribute-based categorization, emphasizing the number of intelligence information topics and not the circumstances in which the particular information types are used (Christensen et al., 2003). The development of a circumstances-based categorization of intelligence information topics would be very useful for both, competitive intelligence and innovation, research streams.

\subsubsection{Company types, intelligence information and innovation}

Existing research literature on the relationship between intelligence information and innovation performance deals mainly with the sources of information and not with volume and diversity (Bommer et al., 2004, Souirais, 2001, 2002, Freel, 2003). In most cases, the focus is on large or R\&D intensive companies (Bommer, 2004). One of the few 
research studies on small companies (Hadjimanolis, 2002) finds that small companies using more sources of technological and competitive information tend to be more innovative. Another researcher (Lehtimaki, 1991) studies the variety of efficient information sources of new product ideas in the case of several different industries.

Souitaris (2001) points out that, in the case of large companies, general information about market and technological trends is positively associated with the firm's innovation performance. He demonstrates a positive association between co-operation with external organizations and innovation performance. MacPherson (1997) also finds a positive connection between innovation success and the use of external sources of scientific and technical expertise. Gemunden et al. (1992) report that close contact and collaboration with lead users, cooperation with universities and research institutes, and cooperation with R\&D units of other companies, all show a highly significant influence on technological innovation success. Customers are the greatest source of successful new product ideas (Gemunden et al., 1992).

Freel (2003) finds that the innovation focus of supplier-technology dominated companies is concentrated on cost-reducing process technologies to meet the demands of highly price-sensitive customers. However, given the generally weak in-house $R \& D$ and engineering capabilities, suppliers are the likely source of new or improved process technologies. Since supplier-technology dominated companies are believed to make only a minor contribution to their process and product technology, one would anticipate a limited association between internal resources and innovation. 
Small specialized suppliers have a focus on product innovations, which predetermines a positive association between innovativeness and customer collaboration (Freel, 2003). Their in-house capabilities are expected to make a significant contribution to both product and process innovations.

The innovation focus of many small science-based companies is a balance between products and processes (Freel, 2003). Process technology is largely developed in-house or sourced from suppliers, whilst product technology is extended internally and based upon the rapid development of the underlying sciences in the universities and elsewhere. Thus, for small science-based companies, there is a role for universities in product innovation and for suppliers in process innovation, complementing their extensive inhouse capabilities. Their innovation-related collaboration with customers, competitors and government agencies is likely to be limited.

\subsection{Lessons learned from the literature review}

This section describes the five key lessons learned from the review of the literature.

\section{Need to study how competitive intelligence information affects innovation}

The innovation performance of a company depends on its ability to acquire, manage and use external and internal competitive intelligence information to make decisions about innovation (Julien et al., 1998; Tidd et al., 2001; Weerawardena et al., 2002; Souitaris, 2001, 2002). Although the relationship between intelligence information management 
and innovation performance of small companies is deemed to be important, little is known about it (Julien et al., 1998; Audet, 2003; Savioz, 2004). Existing studies focus on large companies and on the analysis of information sources (Souitrais, 2001, 2002; Freel, 2003; Bommer \& Jalais, 2004). There are no studies examining the relationship between competitive intelligence information and small company's innovation performance. The study of the relationship between intelligence information and innovation performance requires a framework that includes a broad variety of intelligence information topics such as the one developed by Gordon (2002).

\section{Examine small service companies}

Service innovation should be an integral part of a firm's innovation strategy (Weerawardena et al., 2002). Service innovation research has focused on new financial services. Only recently researchers have begun to address issues concerned with the wide span of services offered (Johne et al., 1998). The service industry sector is experiencing a significant growth in Canada (Canadian Federation of Independent Business, Canadian Manufacturers and Exporters \& RBC Financial Group, 2002) and worldwide (Weerawardena, 2003). There is a need to explicitly study the innovation performance effect of service innovation in high-technology, traditional manufacturing and small service companies (Windrum et al., 1999; Martin et al., 1993; Coyne, 1993; Easingwood et al., 1989; Kaplan, 2000; Morris et al., 1996).

\section{Use multiple dimensions to measure innovation performance}

Multiple innovative performance indicators can offer a better understanding of innovation performance (Saviotti \& Metcalfe, 1984; Souitaris, 2002; Hagedoorn \& Cloodt, 2003). 
The innovation indicators should equally take into account product, process and service types of innovation (Weerawardena et al., 2002).

\section{Company type may affect innovation performance}

Results obtained by Souitaris (2002) and Freel (2003) suggest that company type affects the rate of technological innovation. A Pavitt-like (Pavitt, 1984; Tidd et al., 2001) classification applied to small companies should integrate high-tech, traditional manufacturing and services companies.

The number of intelligence information topics used by companies to make innovation decisions affects innovation performance

The number of intelligence information topics used is expected to be positively associated with the innovation performance of small firms. However, currently there are no studies that directly examine this relationship (Audet, 2003; Julien et al., 1998). 


\section{RESEARCH PROPOSITIONS}

The objective of this thesis is to examine how company type and the number of CI information topics small companies use to make decisions on new products, processes, services and patents affect the innovation performance of IRAP funded companies.

\subsection{Research questions}

The research questions are:

- Does company type affect innovation performance?

- Does the number of intelligence information topics used by companies to make new product, process, service and patent decisions affect their innovation performance?

- Does company type affect the relationship between the number of intelligence information topics used to make decisions and innovation performance?

Figure 3 provides the research model used in this thesis.

Figure 3: Research model

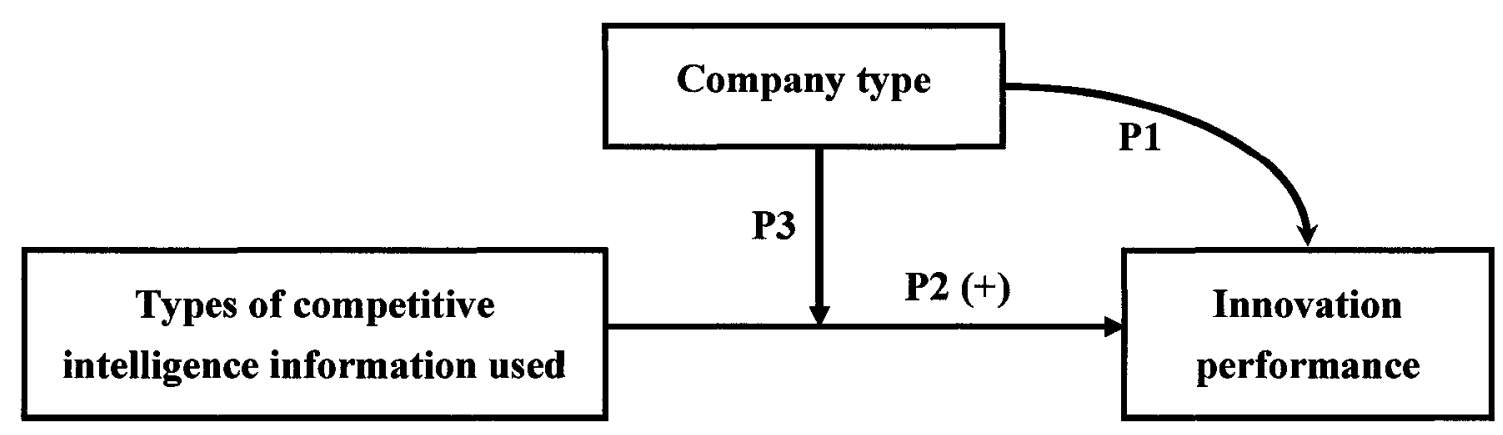


P1 in the model shown in Figure 3 illustrates the relationship between company type and innovation performance. It will be used to confirm that company type affects the innovation performance of small companies. P2 illustrates the relationship between (i) the number of competitive intelligence topics used to innovate and (ii) innovation performance.

In the research model shown in Figure 4, P3 illustrates the role of company type as a moderator of the relationship between the different competitive intelligence topics used to innovate and innovation performance.

\subsection{Propositions development}

Studies have shown that company type affects innovation performance of large (Souitaris, 2002) and small (Freel, 2003) companies. Pavitt et al. (1989) finds that the number of innovations is higher for companies with access to a wide array of technologies (such as new technology-based firms) and companies that continuously improve production efficiency (such as specialized suppliers). The number of innovations is lower in companies that lack in-house technical expertise (such as supplier technology-dominated and service companies).

Proposition 1 is used to confirm previous findings using the sample of companies funded by the IRAP. Therefore, 
Proposition 1. Company type affects the innovation performance of IRAP funded small companies.

For the purpose of this study, IRAP funded companies are organized into three company types: new technology-based companies, specialized suppliers and service companies. New technology-based companies and specialized suppliers focus on product and process development while service companies' focus on service development. Proposition 1 was split into two parts:

Proposition 1a. New technology-based companies and specialized suppliers introduce a larger number of new products and new processes than service companies.

Proposition 1b. Service companies introduce a larger number of new services than new technology-based companies and specialized suppliers.

Technology-based companies patent the technologies they develop. Proposition 1 can be extended to focus on patents. Therefore,

Proposition 1c. New technology-based companies have a larger number of new patents than specialized suppliers and service companies.

The greater the use of competitive intelligence information the greater a company's 
competitive performance (Audet, 2003; Julien et al., 1998). MacPherson (1997) found a positive relationship between the number of external sources of scientific and technical expertise used to develop new products and innovation success. Souitaris (2001) found a positive association between competitive information used (i.e., information on market and technological trends and information on specific companies) and the innovativeness of large companies. It is surmised that small companies that innovate using information comprised of many different topics perform better than small companies that use information comprised of fewer topics. Small companies that are able to collect and act upon information comprised of many different topics are expected to introduce more products, processes and services as well as file more patents. Therefore,

Proposition 2. The number of different intelligence information topics used by IRAP funded companies is positively related to their innovation performance. 


\section{RESEARCH METHOD}

\subsection{Unit of analysis}

The unit of analysis is a small company funded by the IRAP program.

\subsection{Sample}

The sample is comprised of small, IRAP funded companies, located in Ontario, Quebec and the Maritimes.

\subsection{Study period}

The time period for this research spans from January, 2003 to November 30, 2004.

The research was conceptualized from January, 2003 to January, 2004. The methodology, the data collection procedure and the questionnaire were discussed with IRAP's representatives from January to March, 2004. The final version of the questionnaire was developed and tested from March to July, 2004. The questionnaire was approved by IRAP's executives and the Carleton University Research Ethics Committee by August 6, 2004. The data was collected in the period of September 1 to November 1, 2004. Data analysis and results documentation was accomplished from November 1 to November 30 , 2004. 


\subsection{Measurement of variables}

\subsubsection{Company type}

For the purpose of this study, we use a company classification comprising four company types: new technology-based, specialized supplier, supplier technology-dominated, and service company types. It is based on the small company classification proposed by Tidd et al (2001, p. 131) with the following differences: (i) the Superstar companies are excluded since there are essentially large firms and (ii) the service companies are considered as a separate company type. The suggested company classification makes it possible to examine the role of $\mathrm{CI}$ information for the innovation performance of service companies as well as the innovative role of new services introduced by new technology based and specialized supplier firms The main characteristics of the four company types are listed below.

New technology-based companies (in many cases start-ups) deal with new and emerging technologies in electronics, photonics, biotechnology, chemicals, advanced materials and software. Their main sources of technology are internal R\&D and academic research. Specialized suppliers are usually producer of machines, components, instruments and software. The source of their technology is their own engineering design team and advanced lead users.

Supplier technology-dominated companies are producers in the traditional industries such as textile, wood, food, agriculture, housing, etc. They acquire their technology from their suppliers and users, through production learning and research extension services. Service companies are those engaged in services industries such as finances, retailing, 
publishing, travel, e-business, etc. The sources of their technology are their own software and information system departments, suppliers and consultant companies.

IRAP funded companies were organized into the above four company types using the logic shown in Figure 4. A company is classified into one of the four types based on the responses to questions 3, 4, and 5 included in the questionnaire shown as Appendix D.

Figure 4: Logic used to classify companies

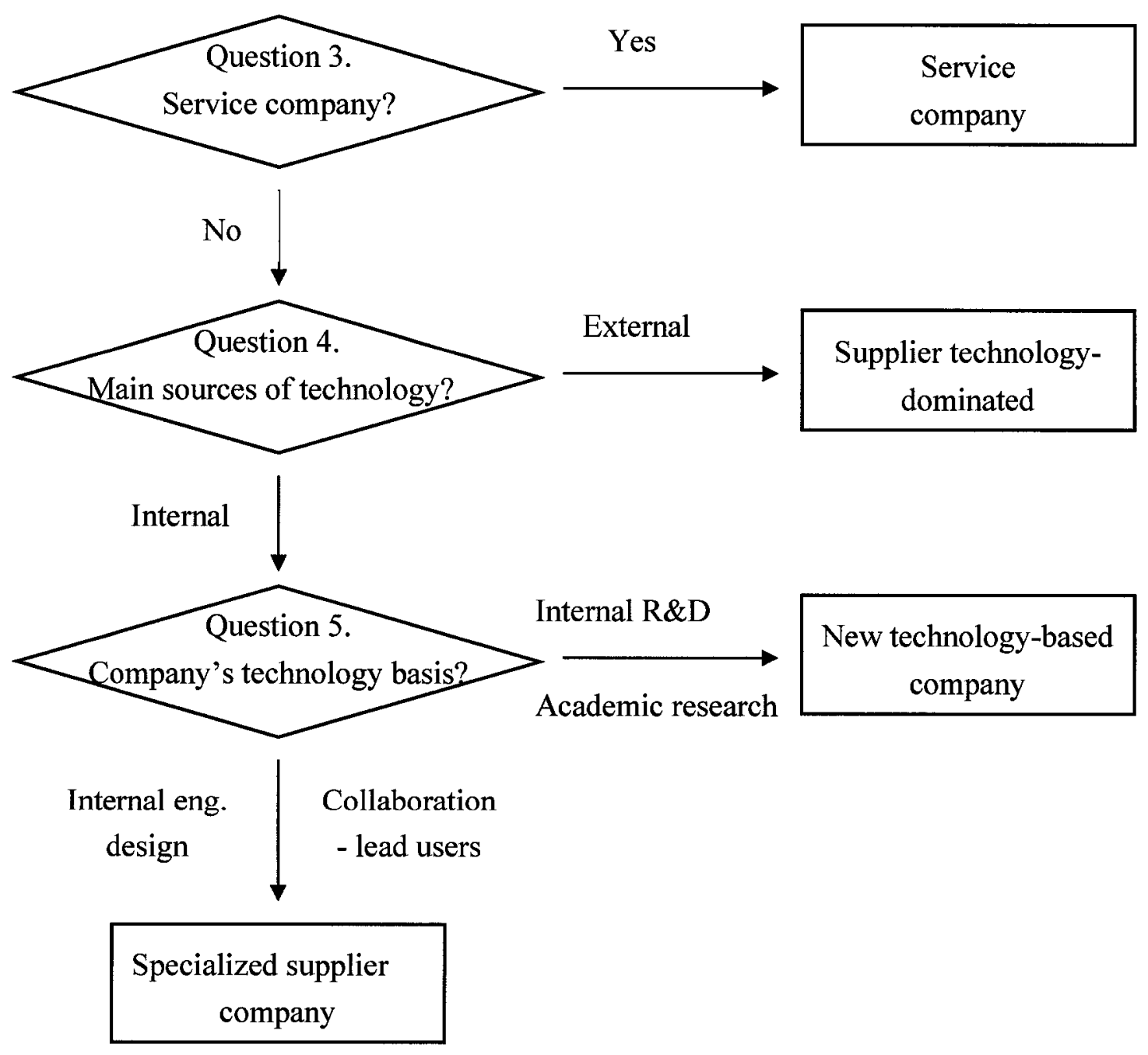


If the answer to question number 3, "Is your company a service company?" was "Yes", then the company was classified as a service company.

If the answer to question 3, "Is your company a service company?" was "No", the answer to question 4, "What are the main sources of your company's technology?" was examined. If the answer to question 4 was "External", the company was classified as a supplier technology-dominated company.

If the answer to question 4 was "Internal", the answer to question 5, "What is your company's technology based on?" was examined. If the answer to question 5 was "Mostly internal R\&D and/or appropriation of academic research results", the company was classified as a new technology-based company.

If the answer to question 5 was "Mostly internal engineering design and/or collaboration with lead users", the company was classified as a specialized supplier company.

\subsubsection{Number of competitive intelligence topics}

The competitive intelligence topics used in this thesis are those identified by Gordon (2002, p. 115). These topics are organized into four categories: industry, customer, competitor and company, and are shown in Appendix C.

Company respondents were asked whether or not information on the topics shown in Appendix $\mathrm{C}$ were used to make decisions on new products, processes, services or patents since June 2001. These questions were included in the questionnaire shown in Appendix 
D. A sample question has the following format:

Question: Since June 2001, did your company make decisions on new products, processes services or patents based on information about:

- the evolution, ongoing changes in, or projected future state of your industry?<smiles></smiles>

The total number of competitive intelligence topics was obtained by adding all the "Yes" responses to the questions shown in Appendix D.

The total number of competitive intelligence topics was broken down into the four topic categories used by Gordon (2002). Thus, the total number of competitive intelligence topics used equals the sum of the industry-related topics, customer-related topics, competitor-related topics, and company-related topics.

\subsubsection{Innovation performance}

The responses to questions 10,11,12 and 13 in the questionnaire included as Appendix

$\mathrm{D}$ were used to measure innovation performance. Innovation performance was measured as:

1. Number of technologically new products introduced since June 2001.

2. Number of technologically new manufacturing processes introduced since June 2001.

3. Number of technologically new services introduced since June 2001.

4. Number of patents filed since June 2001 . 
The choice of this set of innovation performance variables was based on the OSLO manual (Organization for Economic Co-operation and Development, 1997). The definitions of new product, process and service are shown in Appendix B.

\subsection{Questionnaire}

An eight-page questionnaire was used to collect the data for this research. An initial version of the questionnaire was pre-tested by the innovation and network advisor for the IRAP's Quebec region, the competitive technical intelligence coordinator of the Canadian Institute for Scientific and Technical Information, two of the IRAP's industry technology advisors (one from Quebec and one from Ontario), and two executive managers from Ottawa companies. All the above individuals were asked to assist in the final refinement of questions to assure that they were as clear and unambiguous. The questionnaire was modified based on the feedback received.

Carleton University Research Ethics Committee approved the questionnaire used to collect the data on August 6. The questionnaire is included in Appendix D.

A professional translator translated the questionnaire into French. The French language version was tested and improved by the IRAP-Quebec innovation and network advisor and the CI coordinator of the Canadian Institute for Scientific and Technical Information.

The first two pages of the questionnaire outline the objectives of the research and provide definitions of new products, new processes and new services. 
Questions 1 and 2 asked respondents to identify the year the company was incorporated and the approximate number of employees over the last five years. The response to question 1 was used to make sure that all companies in the samples were in business at least two years.

The response to question 2 was used to make sure that all companies in the sample have a number of employees less than 500 .

Question 3 asked respondents to identify whether or not the company was a service company. Question 4 asked whether the main source of the company's technology was mostly external or internal. Question 5 asked whether the company's technology was based on mostly (i) internal R\&D and/or an appropriation of academic research results or (ii) internal engineering design and/or collaboration with lead users. The responses to questions 3, 4 and 5 were used to classify companies using the logic shown in Figure 4.

Questions 6, 7,8 and 9 asked a respondent to indicate whether or not the company had used a competitive intelligence information topic when making decisions on new products, processes, services or patents. Question 6 was comprised of sub-questions on topics pertaining to the industry. Question 7 was comprised of sub-questions on topics pertaining to customers. Question 8 was comprised of sub-questions on topics pertaining to competitors. Question 9 was comprised of sub-questions on topics pertaining to the company. 
The responses associated with questions $6,7,8$ and 9 were used to calculate the number of competitive intelligence information topics used by companies to make decisions on new products, processes, services and patents.

Questions 10,11, and 12 asked respondents to identify the number of new products, processes, and services introduced by the company since June 2001. Question 13 asked respondents to identify the number of patents filed by the company since June 2001 .

The responses to questions $10,11,12$ and 13 were used to measure innovative performance.

\subsection{Data collection}

The IRAP regional executives agreed to distribute the questionnaire shown in Appendix $\mathrm{D}$ and assist in the data collection.

A four-step process was followed to collect the data:

Step1: The IRAP's regional directors for Ontario, Quebec and the Maritimes selected 20 Industry Technology Advisors who were to distribute and collect the questionnaires to their client companies.

Step 2: A letter and the questionnaire in both official languages were sent to the IRAP's Industry Technology Advisors. The letter introduced the researcher and the thesis supervisor and explained the objective of the research, and the procedure to be followed to distribute and collect data from IRAP funded companies. 
Step 3: Each Industry Technology Advisor sent the questionnaire to five IRAP funded companies.

Step 4: Each Industry Technology Advisor collected the questionnaires returned from the companies and sent them back to the researcher.

This four-step data collection process was the one agreed to by both IRAP's Directors and the Carleton University Ethics Board. The process maintained the full confidentiality of IRAP's clients. Thus, the researcher was only able to identify the company type, the number of employees in the last 5 years, the types of intelligence information used since June 2001 to make decision on new products, new processes, new services and new patents as well as the number of new products, new processes, new services and new patents introduced since June 2001.

\subsection{Data analysis}

The SPSS software was used to provide descriptive statistics for all the variables used in this research. To decide whether or not a variable was normally distributed, its Kurtosis and Skewness statistics were examined. A variable was considered to be normally distributed when its skewness and kurtosis were less than twice their standard errors.

ANOVA and Bonferroni tests were used to test Proposition 1, "Company type affects the innovation performance of IRAP funded companies" and its three sub-propositions 1a, 1b 
and 1c. For each company type, the ANOVA test was used to compare the means of the innovation performance variables. The Welch's variance-weighted ANOVA test was used to verify the ANOVA results. The Welch test takes specifically into account the unequal sizes of the three groups of companies in the sample corresponding to each company type.

The Bonferroni test was used to examine pairs of company types with significant statistical difference in the means of each innovation measure. The Games-Howell test was used to verify the Bonferroni test results. The Games-Howell takes specifically into account the unequal sizes and the unequal variances of the three groups of companies in the sample corresponding to each of company types.

For each company type, a stepwise linear regression procedure was used to test Proposition 2 "The number of different intelligence information topics used by IRAP funded companies is positively related to their innovation performance." The SPSS stepwise linear regression with forward inclusion procedure was used to include independent variables. To enter an independent variable, the variable had to meet the following criteria: probability-of-F-to-enter $<=.05$. A variable was removed from the model if the probability-of-F-to-remove $>=0.1$.

The stepwise linear regression models used the four innovation performance variables as the dependent variables and the number of information topics pertaining to industry, customer, competitor, and company information as the independent variables. 


\section{RESEARCH RESULTS}

\subsection{Sample}

Twenty of the IRAP's Industry Technology Advisors distributed questionnaires to 100 companies and collected completed questionnaires from 57 companies. Thus, $57 \%$ of the contacted companies returned completed questionnaires.

Eleven of the 57 received questionnaires were excluded because responses to a significant number of questions were missing. Of the 46 companies that submitted completed questionnaires (37 in English and 9 in French), only one was of the supplier technology-dominated type. Given the latter fact, it was decided to eliminate supplier technology-dominated company category from the sample. Thus, the sample used for analysis in this study was comprised of 45 IRAP funded companies operating in Ontario, Quebec and the four Maritime provinces. Table 3 provides the frequency distribution of the 45 companies in the sample by company type. The sample was comprised of 20 new technology-based companies, 15 specialized suppliers, and 15 service companies.

Table 3: Frequency distribution of companies in the sample by company type

\begin{tabular}{|l|l|l|}
\hline Type & Frequency & Percent \\
\hline New technology-based companies & 20 & 44.4 \\
\hline Specialized suppliers & 10 & 22.2 \\
\hline Service companies & 15 & 33.3 \\
\hline Total & 45 & 100.0 \\
\hline
\end{tabular}

Table 4 provides the number of company employees' frequency distribution. The 
minimum and maximum numbers of employees are 3 and 250, respectively.

Table 4: Frequency distribution of companies in the sample by number of employees.

\begin{tabular}{|c|c|c|c|}
\hline $\begin{array}{l}\text { Number of } \\
\text { employees }\end{array}$ & Frequency & Percent & $\begin{array}{l}\text { Cumulative } \\
\text { Percent } \\
\end{array}$ \\
\hline 3 & 3 & 6.7 & 6.7 \\
\hline 4 & 1 & 2.2 & 8.9 \\
\hline 5 & 5 & 11.1 & 20.0 \\
\hline 6 & 2 & 4.4 & 24.4 \\
\hline 7 & 4 & 8.9 & 33.3 \\
\hline 8 & 2 & 4.4 & 37.8 \\
\hline 9 & 1 & 2.2 & 40.0 \\
\hline 10 & 3 & 6.7 & 46.7 \\
\hline 12 & 4 & 8.9 & 55.6 \\
\hline 22 & 1 & 2.2 & 57.8 \\
\hline 24 & 2 & 4.4 & 62.2 \\
\hline 25 & 1 & 2.2 & 64.4 \\
\hline 26 & 1 & 2.2 & 66.7 \\
\hline 27 & 1 & 2.2 & 68.9 \\
\hline 30 & 1 & 2.2 & 71.1 \\
\hline 32 & 1 & 2.2 & 73.3 \\
\hline 33 & 1 & 2.2 & 75.6 \\
\hline 35 & 1 & 2.2 & 77.8 \\
\hline 45 & 1 & 2.2 & 80.0 \\
\hline 50 & 1 & 2.2 & 82.2 \\
\hline 55 & 2 & 4.4 & 86.7 \\
\hline 60 & 1 & 2.2 & 88.9 \\
\hline 85 & 2 & 4.4 & 93.3 \\
\hline 150 & 1 & 2.2 & 95.6 \\
\hline 170 & 1 & 2.2 & 97.8 \\
\hline 250 & 1 & 2.2 & 100.0 \\
\hline Total & 45 & 100.0 & \\
\hline
\end{tabular}


Figure 5 shows histograms of the number employees for each company type.

Figure 5: Histogram of the number of company employees per company type

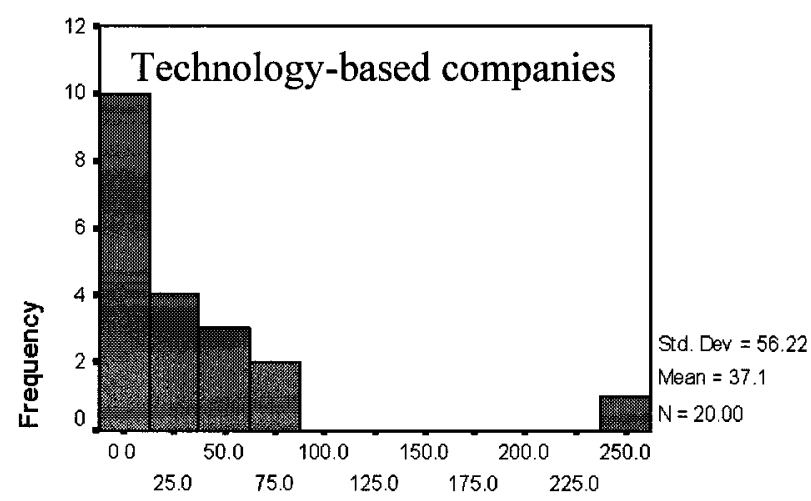

number of employees in 2004

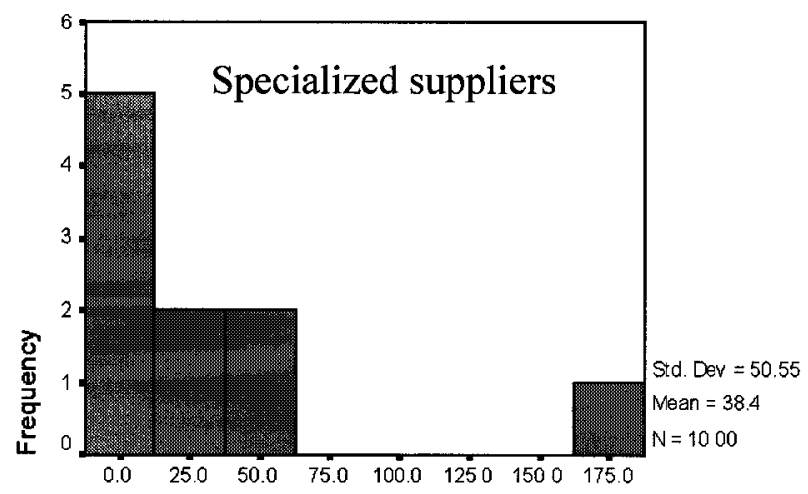

number of employees in 2004

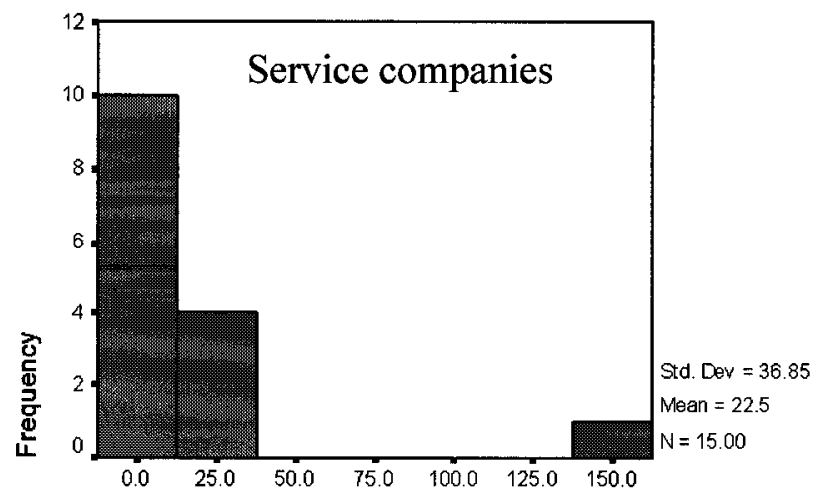

number of employees in 2004 
Table 5 provides the frequency distribution of companies in the sample per year of incorporation.

Table 5: Distribution of companies per year of incorporation

\begin{tabular}{|c|c|c|}
\hline Year & Frequency & Percent \\
\hline 1972 & 1 & 2.2 \\
\hline 1974 & 2 & 4.4 \\
\hline 1978 & 1 & 2.2 \\
\hline 1979 & 1 & 2.2 \\
\hline 1982 & 1 & 2.2 \\
\hline 1985 & 3 & 6.7 \\
\hline 1986 & 2 & 4.4 \\
\hline 1987 & 2 & 4.4 \\
\hline 1988 & 1 & 2.2 \\
\hline 1990 & 1 & 2.2 \\
\hline 1991 & 1 & 2.2 \\
\hline 1992 & 1 & 2.2 \\
\hline 1993 & 1 & 2.2 \\
\hline 1994 & 3 & 6.7 \\
\hline 1995 & 1 & 2.2 \\
\hline 1996 & 3 & 6.7 \\
\hline 1997 & 1 & 2.2 \\
\hline 1998 & 5 & 11.1 \\
\hline 1999 & 3 & 6.7 \\
\hline 2000 & 8 & 17.8 \\
\hline 2002 & 3 & 6.7 \\
\hline Total & 45 & 100.0 \\
\hline
\end{tabular}

Figure 6 shows histograms of the years of incorporation for each company type. 
Figure 6: Histograms of the years of incorporation for each company type
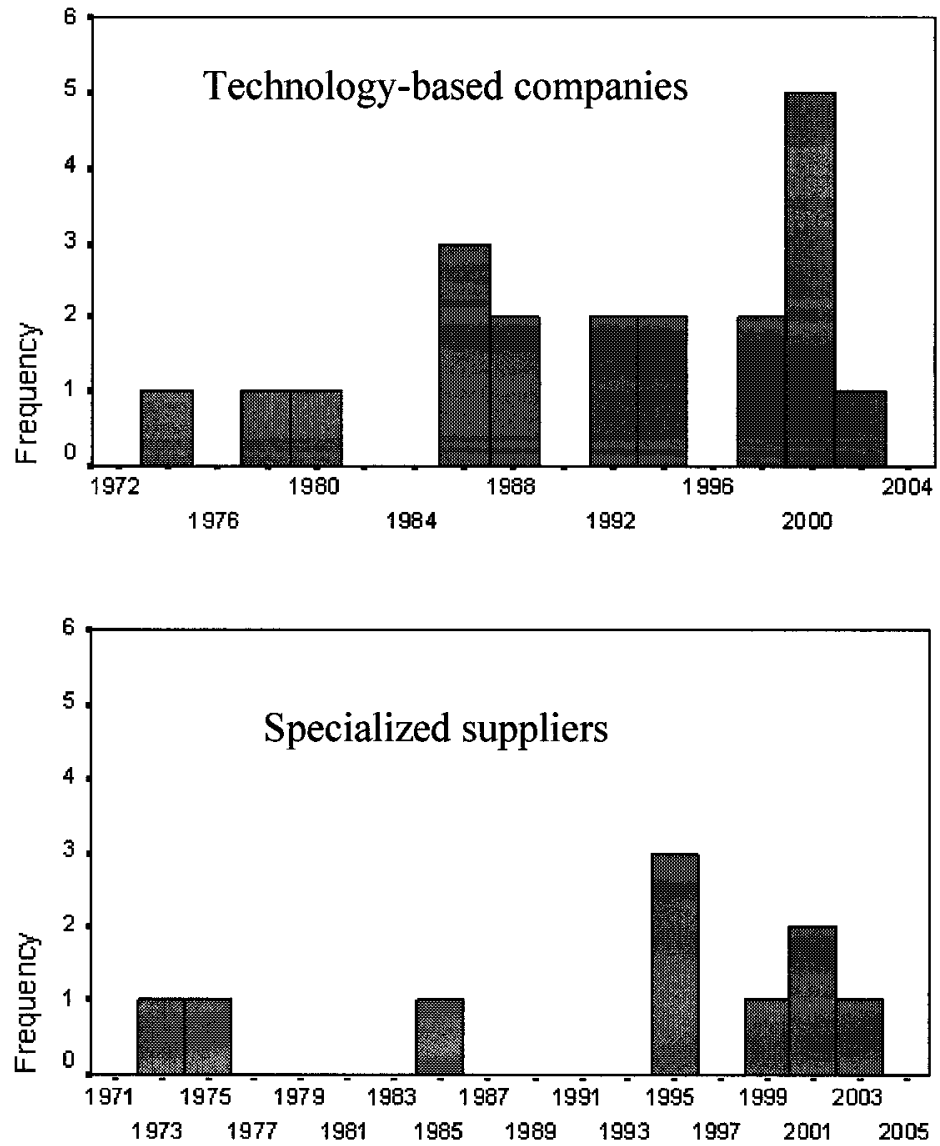

year of company incorporation

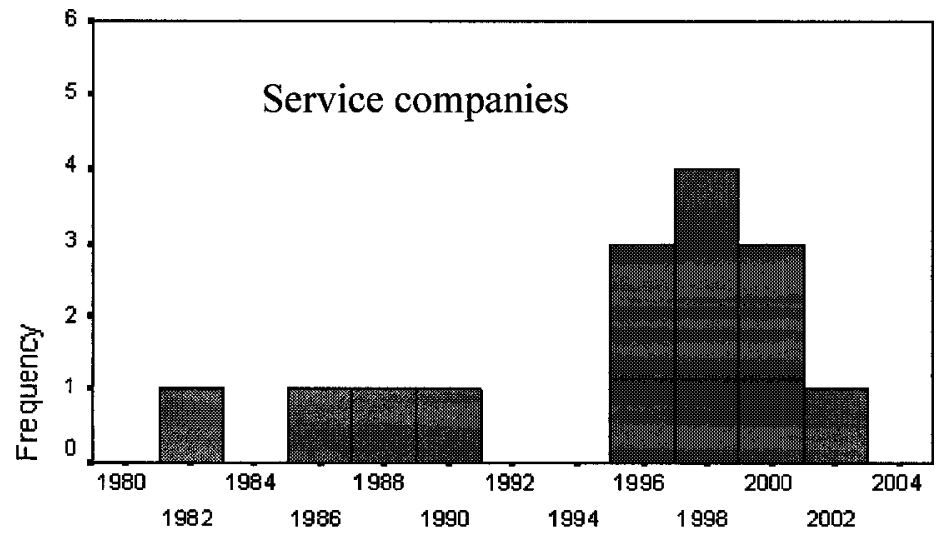

year of company incorporation 


\subsection{Descriptive statistics}

Table 6 shows the descriptive statistics of the variables used in this research. To decide whether or not a variable was normally distributed, its Kurtosis and Skewness statistics were examined. A variable was considered to be normally distributed when its Skewness and Kurtosis statistics were less than twice their standard errors.

Table 6: Descriptive statistics of the variables used in this research

\begin{tabular}{|c|c|c|c|c|c|c|}
\hline & Mean & Variance & Skewness & $\begin{array}{l}\text { Skewness } \\
\text { standard } \\
\text { error }\end{array}$ & Kurtosis & $\begin{array}{c}\text { Kurtosis } \\
\text { standard } \\
\text { error }\end{array}$ \\
\hline $\begin{array}{c}\text { number of } \\
\text { information } \\
\text { topics used }\end{array}$ & 25.69 & 57.628 & .272 & .354 & -.010 & .695 \\
\hline $\begin{array}{c}\text { number of } \\
\text { industry } \\
\text { topics used }\end{array}$ & 5.04 & 4.907 & .467 & .354 & -.040 & .695 \\
\hline $\begin{array}{c}\text { number of } \\
\text { customer } \\
\text { topics used }\end{array}$ & 6.60 & 3.518 & -.466 & .354 & -.797 & .695 \\
\hline $\begin{array}{c}\text { number of } \\
\text { competitor } \\
\text { topics used }\end{array}$ & 5.02 & 11.386 & .359 & .354 & -.773 & .695 \\
\hline $\begin{array}{c}\text { number of } \\
\text { company } \\
\text { topics used }\end{array}$ & 9.02 & 4.659 & -.612 & .354 & -.163 & .695 \\
\hline $\begin{array}{c}\text { number of } \\
\text { new products }\end{array}$ & 4.33 & 22.591 & 2.295 & .354 & 6.244 & .695 \\
\hline $\begin{array}{c}\text { number of } \\
\text { new processes }\end{array}$ & 3.69 & 35.583 & 2.479 & .354 & 5.490 & .695 \\
\hline $\begin{array}{c}\text { number of } \\
\text { new services }\end{array}$ & 1.67 & 4.591 & 1.689 & .354 & 3.823 & .695 \\
\hline $\begin{array}{c}\text { number of } \\
\text { new patents }\end{array}$ & 1.16 & 6.498 & 4.048 & .354 & 20.010 & .695 \\
\hline
\end{tabular}


The results in Table 6 indicate that the four variables measuring innovation performance are not normally distributed. The following four variables are skewed to the right: number of new products, number of new processes, number of new services, and number of new patents filed.

To normalize the four measures of innovation performance, a transform of the type $\mathrm{X}$ : (X $+\mathrm{C})^{\mathrm{N}}$ was used, where $\mathrm{C}$ is constant and $\mathrm{N}$ is a rational number (Garson, 2004). Values of $\mathrm{N}$ that are less than one correct right skewness. To normalize the innovation performance variables $C$ was made equal to 0 and the $N$ values were $1 / 3$ for new products, $1 / 3$ for new processes, $1 / 2$ for new services, and $1 / 5$ for new patents filed.

Table 7 provides the descriptive statistics for the four normalized variables.

Table 7: Descriptive statistics of the normalized innovation performance variables

\begin{tabular}{|c|c|c|c|c|c|c|}
\hline & Mean & Variance & Skewness & $\begin{array}{c}\text { Skewness } \\
\text { Standard } \\
\text { error }\end{array}$ & Kurtosis & $\begin{array}{c}\text { Kurtosis } \\
\text { standard } \\
\text { error }\end{array}$ \\
\hline $\begin{array}{c}\text { number of new } \\
\text { products**(1/3) }\end{array}$ & 1.426 & .352 & -.235 & .354 & 1.214 & .695 \\
\hline $\begin{array}{c}\text { number of new } \\
\text { processes**(1/3) }\end{array}$ & 1.089 & .712 & .212 & .354 & -.496 & .695 \\
\hline $\begin{array}{c}\text { number of new } \\
\text { services**(1/2) }\end{array}$ & .913 & .852 & .404 & .354 & -1.081 & .695 \\
\hline $\begin{array}{c}\text { number of new } \\
\text { patents**(1/5) }\end{array}$ & .446 & .350 & .665 & .354 & -1.381 & .695 \\
\hline
\end{tabular}




\subsection{Innovation performance}

Table 8 shows the descriptive statistics of the innovation performance variables by company type.

Table 8: Descriptive statistics of innovation performance means by company type

\begin{tabular}{|c|c|c|c|c|c|c|c|}
\hline $\begin{array}{c}\text { Innovation } \\
\text { measure }\end{array}$ & Company Type & $\mathbf{N}$ & Mean & $\begin{array}{c}\text { Std. } \\
\text { Deviation }\end{array}$ & $\begin{array}{c}\text { Std. } \\
\text { Error }\end{array}$ & Min & Max \\
\hline $\begin{array}{c}\text { number of new } \\
\text { products**(1/3) }\end{array}$ & $\begin{array}{c}\text { New technology- } \\
\text { based }\end{array}$ & 20 & 1.51 & .517 & .115 & 1.00 & 2.88 \\
\hline & $\begin{array}{c}\text { Specialized } \\
\text { supplier }\end{array}$ & 10 & 1.55 & .344 & .108 & 1.26 & 2.35 \\
\hline & Service & 15 & 1.22 & .773 & .199 & .00 & 2.47 \\
\hline & Total & 45 & 1.42 & .593 & .088 & .00 & 2.88 \\
\hline $\begin{array}{c}\text { number of new } \\
\text { processes**(1/3) }\end{array}$ & $\begin{array}{c}\text { New technology- } \\
\text { based }\end{array}$ & 20 & 1.04 & .815 & .182 & .00 & 2.71 \\
\hline & $\begin{array}{c}\text { Specialized } \\
\text { supplier }\end{array}$ & 10 & 1.402 & .963 & .304 & .00 & 2.92 \\
\hline & Service & 15 & .939 & .800 & .206 & .00 & 2.71 \\
\hline $\begin{array}{c}\text { Total } \\
\text { number of new }\end{array}$ & $\begin{array}{c}\text { New technology- } \\
\text { based }\end{array}$ & 20 & .559 & .751 & .168 & .00 & 2.00 \\
\hline & $\begin{array}{c}\text { Specialized } \\
\text { supplier }\end{array}$ & 10 & .400 & .699 & .221 & .00 & 2.00 \\
\hline & Service & 15 & 1.726 & .722 & .186 & .00 & 3.16 \\
\hline & Total & 45 & .913 & .923 & .137 & .00 & 3.16 \\
\hline & $\begin{array}{c}\text { Total } \\
\text { Specialized } \\
\text { supplier }\end{array}$ & 10 & .418 & .688 & .217 & .00 & 1.72 \\
\hline $\begin{array}{c}\text { Service } \\
\text { patents**(1/5) }\end{array}$ & $\begin{array}{c}\text { New technology- } \\
\text { based }\end{array}$ & 20 & .644 & .607 & .135 & .00 & 1.43 \\
\hline & 45 & .446 & .591 & .0881 & .00 & 1.72 \\
\hline
\end{tabular}


Table 9 provides the results from the one-way ANOVA test. The results indicate that there is a statistically significant difference between the squared number of new services $(\mathrm{P}<0.001)$ across different company types and the number of new patents to the power of $1 / 5(\mathrm{P}<0.1)$ across different company types.

Table 9: ANOVA results for differences in innovation performance means

\begin{tabular}{|c|c|c|c|c|c|c|}
\hline & & $\begin{array}{c}\text { Sum of } \\
\text { Squares }\end{array}$ & df & $\begin{array}{c}\text { Mean } \\
\text { Square }\end{array}$ & F & Sig. \\
\hline $\begin{array}{c}\text { number of new } \\
\text { products**(1/3) }\end{array}$ & Between Groups & .961 & 2 & .480 & 1.389 & .261 \\
\hline & Within Groups & 14.526 & 42 & .346 & & \\
\hline & Total & 15.487 & 44 & & & \\
\hline $\begin{array}{c}\text { number of new } \\
\text { processes**(1/3) }\end{array}$ & Between Groups & 1.354 & 2 & .677 & .948 & .396 \\
\hline & Within Groups & 29.994 & 42 & .714 & & \\
\hline & Total & 31.348 & 44 & & & \\
\hline $\begin{array}{c}\text { number of new } \\
\text { services**(1/2) }\end{array}$ & Between Groups & 15.042 & 2 & 7.521 & 14.074 & .000 \\
\hline & Within Groups & 22.445 & 42 & .534 & & \\
\hline & Total & 37.487 & 44 & & & \\
\hline $\begin{array}{c}\text { number of new } \\
\text { patents**(1/5) }\end{array}$ & Between Groups & 1.706 & 2 & .853 & 2.619 & .085 \\
\hline & Within Groups & 13.678 & 42 & .326 & & \\
\hline & Total & 15.384 & 44 & & & \\
\hline
\end{tabular}

Table 10 shows the results from the Welch test. These Welch test results confirm the results obtained using the ANOVA test. The means of the square roots of the number of new services are different across company types. Similarly, the means of the number of new patents to the $5^{\text {th }}$ root are different across company types. 
Table 10: Results of performing the Welch test

\begin{tabular}{|c|c|c|c|c|c|}
\hline & Test & Statistic & df1 & df2 & Sig. \\
\hline $\begin{array}{c}\text { number of new } \\
\text { products**(1/3) }\end{array}$ & Welch & 1.080 & 2 & 25.507 & .354 \\
\hline $\begin{array}{c}\text { number of new } \\
\text { processes**(1/3) }\end{array}$ & Welch & .778 & 2 & 22.087 & .471 \\
\hline $\begin{array}{c}\text { number of new } \\
\text { services**(1/2) }\end{array}$ & Welch & 13.996 & 2 & 23.638 & .000 \\
\hline $\begin{array}{c}\text { number of new } \\
\text { patents**(1/5) }\end{array}$ & Welch & 3.232 & 2 & 21.705 & .059 \\
\hline
\end{tabular}

a Asymptotically F distributed.

Table 11 shows the results from the multiple comparison Bonferroni test used to examine pairs of company types with significant statistical difference in the means of the square roots of the number of new services and the number of new patents to the $5^{\text {th }}$ root. The results indicate that there is a statistically significant difference $(\mathrm{P}<0.001)$ between the squared number of new services of service companies and new technology-based companies as well as between service companies and specialized suppliers.

The Bonferroni test results also indicate that there is a statistically significant difference between the number of new patents to the $5^{\text {th }}$ root of service companies and new technology-based companies at $\mathrm{P}<0.1$. 
Table 11: Bonferroni multiple comparison test results

\begin{tabular}{|c|c|c|c|c|c|c|c|}
\hline $\begin{array}{l}\text { Depend. } \\
\text { Variable }\end{array}$ & $\begin{array}{c}\text { Company } \\
\text { type (I) }\end{array}$ & $\begin{array}{c}\text { Company } \\
\text { type }(J)\end{array}$ & $\begin{array}{c}\text { Mean } \\
\text { Diff. } \\
\text { (I-J) } \\
\end{array}$ & $\begin{array}{l}\text { Std. } \\
\text { Error }\end{array}$ & Sig. & $\begin{array}{c}95 \% \\
\text { Confid. } \\
\text { Interval } \\
\end{array}$ & \\
\hline & & & & & & $\begin{array}{l}\text { Lower } \\
\text { Bound }\end{array}$ & $\begin{array}{l}\text { Upper } \\
\text { Bound }\end{array}$ \\
\hline \multirow[t]{4}{*}{$\begin{array}{l}\text { number of new } \\
\text { services }^{* *}(1 / 2)\end{array}$} & $\begin{array}{c}\text { New } \\
\text { technology } \\
\text { based }\end{array}$ & Service & -1.166 & .250 & .000 & -1.789 & -.544 \\
\hline & $\begin{array}{l}\text { Specialized } \\
\text { supplier }\end{array}$ & Service & -1.326 & .298 & .000 & -2.070 & -.582 \\
\hline & Service & $\begin{array}{c}\text { Technology } \\
\text { based }\end{array}$ & 1.166 & .250 & .000 & .544 & 1.789 \\
\hline & Service & $\begin{array}{l}\text { Specialized } \\
\text { supplier }\end{array}$ & 1.326 & .298 & .000 & .582 & 2.070 \\
\hline \multirow[t]{2}{*}{$\begin{array}{c}\text { number of new } \\
\text { patents }^{* *}(1 / 5)\end{array}$} & $\begin{array}{c}\text { New } \\
\text { technology } \\
\text { based }\end{array}$ & Service & .445 & .195 & .083 & -.041 & .931 \\
\hline & Service & $\begin{array}{c}\text { Technology } \\
\text { based }\end{array}$ & -.445 & .195 & .083 & -.931 & .041 \\
\hline
\end{tabular}

* The mean difference is significant at the .05 level.

The multiple comparison Bonferroni test results were confirmed by the Games-Howell test. The Games-Howell test takes into account the inequality of the size of each company type sub-sample. The only slight difference between the results of the two tests is in the fact that the statistical significance of the difference between the number of new patents to the power of $(1 / 5)$ of service companies and new technology-based companies is at $\mathrm{P}<0.5$ level (as compared to $\mathrm{P}<0.1$ in the Bonferroni test). Table 12 shows the Games-Howell test results. 
Table 12: Games-Howell multiple comparison test results

\begin{tabular}{|c|c|c|c|c|c|c|c|}
\hline $\begin{array}{l}\text { Depend. } \\
\text { Variable }\end{array}$ & $\begin{array}{l}\text { Company } \\
\text { type (I) }\end{array}$ & $\begin{array}{l}\text { Company } \\
\text { type (II) }\end{array}$ & $\begin{array}{l}\text { Mean } \\
\text { Diff. } \\
\text { (I-J) }\end{array}$ & $\begin{array}{l}\text { Std. } \\
\text { Error }\end{array}$ & Sig. & $\begin{array}{c}95 \% \\
\text { Confid. } \\
\text { Interval }\end{array}$ & \\
\hline & & & & & & $\begin{array}{l}\text { Lower } \\
\text { Bound }\end{array}$ & $\begin{array}{l}\text { Upper } \\
\text { Bound }\end{array}$ \\
\hline \multirow[t]{4}{*}{$\begin{array}{l}\text { number of new } \\
\text { services**(1/2) }\end{array}$} & $\begin{array}{c}\text { New } \\
\text { technology } \\
\text { based }\end{array}$ & Service & -1.166 & .251 & .000 & -1.784 & -.548 \\
\hline & $\begin{array}{l}\text { Specialized } \\
\text { supplier }\end{array}$ & Service & -1.326 & .289 & .001 & -2.058 & -.594 \\
\hline & Service & $\begin{array}{c}\text { Technology } \\
\text { based }\end{array}$ & 1.166 & .251 & .000 & .548 & 1.784 \\
\hline & Service & $\begin{array}{l}\text { Specialized } \\
\text { supplier }\end{array}$ & 1.326 & .289 & .001 & .594 & 2.058 \\
\hline \multirow[t]{2}{*}{$\begin{array}{c}\text { number of new } \\
\text { patents } \\
* *(1 / 5) \\
\end{array}$} & $\begin{array}{c}\text { New } \\
\text { technology } \\
\text { based }\end{array}$ & Service & .445 & .173 & .038 & .020 & .869 \\
\hline & Service & $\begin{array}{c}\text { Technology } \\
\text { based }\end{array}$ & -.445 & .173 & .038 & -.869 & -.020 \\
\hline
\end{tabular}

* The mean difference is significant at the .05 level. 


\subsection{Innovation performance and number of intelligence information topics}

Linear regression using the forward stepwise procedure was used to explore the relationship between innovation performance and the number of intelligence information topics used to make decisions about product, process and service introduction as well as patent filing. The relationship will be explored using the sample of 45 companies and each of the three sub-samples: new technology-based companies, specialized suppliers and service companies. For each regression model, five potential independent variables were examined for inclusion using the stepwise linear procedure: (i) total number of intelligence information topics used to make decisions, (ii) number of intelligence topics pertaining to industry information used to make decisions, (iii) number of intelligence topics pertaining to customer information used to make decisions, (iv) number of intelligence topics pertaining to competitor information used to make decisions, and (v) number of intelligence topics pertaining to company information used to make decisions.

\subsubsection{Results for the full sample of 45 companies}

For the full sample, no independent variables were included into the regression model when the number of products to the power of $(1 / 3)$, the number of services to the power of $(1 / 2)$, and the number of patents to the power of $(1 / 5)$ were used as dependent variables. Table 13 summarizes the stepwise linear regression results using the number of new processes to the power of (1/3) as the dependent variable. The number of topics pertaining to customer intelligence information was the only independent variable that met the criteria for inclusion into the regression model. 
Table 13: Regression results using number of new processes to the power of $(1 / 3)$ as the dependent variable and the 45 company sample

\begin{tabular}{|c|c|c|c|c|}
\hline $\begin{array}{c}\text { Model } \\
\text { summary }\end{array}$ & R & R Square & $\begin{array}{c}\text { Adjusted R } \\
\text { Square }\end{array}$ & $\begin{array}{c}\text { Std. Error of } \\
\text { the Estimate }\end{array}$ \\
\hline $\mathbf{1}$ & .470 & .221 & .203 & .754 \\
\hline
\end{tabular}

a Predictors: (Constant), number of topics pertaining to customer info

ANOVA

\begin{tabular}{|c|c|c|c|c|c|c|}
\hline Model & & Sum of Squares & df & Mean Square & F & Sig. \\
\hline $\mathbf{1}$ & Regression & 6.933 & 1 & 6.933 & 12.210 & .001 \\
\hline & Residual & 24.415 & 43 & .568 & & \\
\hline & Total & 31.348 & 44 & & & \\
\hline
\end{tabular}

a Predictors: (Constant), number of topics pertaining to customer info

b Dependent Variable: number of new processes**(1/3)

\section{Coefficients}

\begin{tabular}{|c|c|c|c|c|c|c|}
\hline & & $\begin{array}{c}\text { Unstandard. } \\
\text { Coefficients }\end{array}$ & & $\begin{array}{c}\text { Standardized } \\
\text { Coefficients }\end{array}$ & $\mathbf{t}$ & Sig. \\
\hline Model & & B & Std. Err & Beta & & \\
\hline $\mathbf{1}$ & (Constant) & -.307 & .415 & & -.740 & .463 \\
\hline & $\begin{array}{c}\text { Number of } \\
\text { topics pertaining } \\
\text { to customers }\end{array}$ & .212 & .061 & .470 & 3.494 & .001 \\
\hline
\end{tabular}

a Dependent Variable: number of new processes $* *(1 / 3)$

Excluded Variables

\begin{tabular}{|c|c|c|c|c|c|c|}
\hline & & Beta In & $\mathbf{t}$ & Sig. & $\begin{array}{c}\text { Partial } \\
\text { Correlation }\end{array}$ & $\begin{array}{c}\text { Collinearity } \\
\text { Statistics }\end{array}$ \\
\hline Model & & & & & & Tolerance \\
\hline $\mathbf{1}$ & $\begin{array}{c}\text { Number of topics } \\
\text { pertaining to industry }\end{array}$ & .258 & 1.627 & .111 & .243 & .696 \\
\hline $\begin{array}{c}\text { Number of topics } \\
\text { pertaining to competitors }\end{array}$ & -.007 & -.050 & .960 & -.008 & .851 \\
\hline & $\begin{array}{c}\text { Number of topics } \\
\text { pertaining to company }\end{array}$ & .006 & .043 & .966 & .007 & .877 \\
\hline & Total number of topics & .095 & .512 & .611 & .079 & .539 \\
\hline
\end{tabular}

a Predictors in the Model: (Constant), number of topics pertaining to customer info

b Dependent Variable: number of new processes**(1/3) 


\subsubsection{Results for the new technology-based sub-sample sample}

For the new technology-based sample, no independent variables were included into the regression model when the number of products to the power of $(1 / 3)$ and the number of patents to the power of $(1 / 5)$ were used as dependent variables.

Table 14 summarizes the stepwise linear regression results using the number of new processes to the power of $(1 / 3)$ as the dependent variable for the new technology-based company sub-sample. The number of topics pertaining to customer intelligence information was the only independent variable that met the criteria for inclusion into the regression model using the sub-sample comprised of new technology-based companies.

Table 14: Results of stepwise linear regression with number of new processes to the power of (1/3) as the dependent variable using the sub-sample comprised of new technology-based companies

\begin{tabular}{|c|c|c|c|c|}
\hline $\begin{array}{c}\text { Model } \\
\text { summary }\end{array}$ & R & R Square & Adj. R Square & Std. Error of the Estimate \\
\hline $\mathbf{1}$ & .621 & .385 & .351 & .657 \\
\hline
\end{tabular}

a Predictors: (Constant), number of topics pertaining to customer info

ANOVA

\begin{tabular}{|c|c|c|c|c|c|c|}
\hline Model & & Sum of Squares & df & Mean Square & F & Sig. \\
\hline 1 & Regression & 4.874 & 1 & 4.874 & 11.283 & .003 \\
\hline & Residual & 7.775 & 18 & .432 & & \\
\hline & Total & 12.649 & 19 & & & \\
\hline
\end{tabular}

a Predictors: (Constant), number of topics pertaining to customer info

b Dependent Variable: number of new processes** $(1 / 3)$

c Selecting only cases for which type of company $=$ new technology-based companies 
Table 14: Continued

Coefficients

\begin{tabular}{|c|c|c|c|c|c|c|}
\hline & & $\begin{array}{c}\text { Unstandard. } \\
\text { Coefficients }\end{array}$ & & $\begin{array}{c}\text { Standard. } \\
\text { Coefficients }\end{array}$ & T & Sig. \\
\hline Model & & B & Std. Err & Beta & & \\
\hline 1 & (Constant) & -.772 & .561 & & -1.377 & .185 \\
\hline & $\begin{array}{c}\text { Number of topics } \\
\text { pertaining to } \\
\text { customers }\end{array}$ & .271 & .081 & .621 & 3.359 & .003 \\
\hline
\end{tabular}

a Dependent Variable: number of new processes**(1/3)

b Selecting only cases for which type of company = new technology-based company

Excluded Variables

\begin{tabular}{|c|c|c|c|c|c|c|}
\hline & & Beta In & $\mathbf{t}$ & Sig. & $\begin{array}{c}\text { Partial } \\
\text { Correlation }\end{array}$ & $\begin{array}{c}\text { Collinearity } \\
\text { Statistics } \\
\end{array}$ \\
\hline Model & & & & & & Tolerance \\
\hline \multirow[t]{4}{*}{1} & $\begin{array}{l}\text { Number of topics } \\
\text { pertaining to industry }\end{array}$ & .084 & .359 & .724 & .087 & .661 \\
\hline & $\begin{array}{c}\text { Number of topics } \\
\text { pertaining to } \\
\text { competitors }\end{array}$ & -.307 & -1.562 & .137 & -.354 & .821 \\
\hline & $\begin{array}{l}\text { Number of topics } \\
\text { pertaining to } \\
\text { company }\end{array}$ & .082 & .383 & .706 & .093 & .790 \\
\hline & $\begin{array}{c}\text { Total number of } \\
\text { topics }\end{array}$ & -.177 & -.643 & .529 & -.154 & .466 \\
\hline
\end{tabular}

a Predictors in the Model: (Constant), number of topics pertaining to customer info

b Dependent Variable: number of new processes**(1/3)

Table 15 summarizes the stepwise linear regression results using the number of new services to the power of $(1 / 2)$ as the dependent variable for the new technology-based company sub-sample. The number of topics pertaining to company information was the only independent variable that met the criteria for inclusion into the regression model using the sub-sample comprised of new technology-based companies. 
Table 15. Results of stepwise linear regression with number of new services to the power of (1/2) as the dependent variable using the sub-sample comprised of new technology-based companies

\begin{tabular}{|c|c|c|c|c|}
\hline $\begin{array}{c}\text { Model } \\
\text { summary }\end{array}$ & R & R Square & Adjusted R Square & Std. Error \\
\hline $\mathbf{1}$ & .509 & .259 & .217 & .665 \\
\hline
\end{tabular}

a Predictors: (Constant), number of topics pertaining to company info

ANOVA

\begin{tabular}{|c|c|c|c|c|c|c|}
\hline Model & & Sum of Squares & df & Mean Square & F & Sig. \\
\hline $\mathbf{1}$ & Regression & 2.776 & 1 & 2.776 & 6.280 & .022 \\
\hline & Residual & 7.957 & 18 & .442 & & \\
\hline & Total & 10.732 & 19 & & & \\
\hline
\end{tabular}

a Predictors: (Constant), number of topics pertaining to company info

b Dependent Variable: number of new services** $(1 / 2)$

c Selecting only cases for which type of company $=$ new technology-based companies

Coefficients

\begin{tabular}{|c|c|c|c|c|c|c|}
\hline & $\begin{array}{c}\text { Unstandard. } \\
\text { Coefficients }\end{array}$ & & $\begin{array}{c}\text { Standard. } \\
\text { Coefficients }\end{array}$ & $\mathbf{t}$ & Sig. \\
\hline Model & & B & Std. Err & Beta & & \\
\hline $\mathbf{1}$ & (Constant) & -1.928 & 1.004 & & -1.921 & .071 \\
\hline & $\begin{array}{c}\text { Number of topics } \\
\text { pertaining to } \\
\text { company }\end{array}$ & .256 & .102 & .509 & 2.506 & .022 \\
\hline
\end{tabular}

a Dependent Variable: number of new services**(1/2)

b Selecting only cases for which type of company = new technology-based companies

Excluded Variables

\begin{tabular}{|c|c|c|c|c|c|c|}
\hline & & Beta In & $\mathbf{t}$ & Sig. & $\begin{array}{c}\text { Partial } \\
\text { Correlation }\end{array}$ & $\begin{array}{c}\text { Collinear. } \\
\text { Statistics }\end{array}$ \\
\hline Model & & & & & & Tolerance \\
\hline $\mathbf{1}$ & Total number of topics & .153 & .466 & .647 & .112 & .396 \\
\hline & $\begin{array}{c}\text { Number of topics } \\
\text { pertaining to industry }\end{array}$ & .000 & .000 & 1.00 & .000 & .689 \\
\hline $\begin{array}{c}\text { Number of topics } \\
\text { pertaining to customers }\end{array}$ & .327 & 1.478 & .158 & .337 & .790 \\
\hline $\begin{array}{c}\text { Number of topics } \\
\text { pertaining to } \\
\text { competitors }\end{array}$ & -.015 & -.058 & .954 & -.014 & .635 \\
\hline
\end{tabular}

a Predictors in the Model: (Constant), number of topics pertaining to company info

b Dependent Variable: number of new services**(1/2) 


\subsubsection{Results for the specialized supplier sub-sample}

For the specialized supplier sub-sample, no independent variables were included into the regression model when the number of products to the power of $(1 / 3)$, the number of services to the power $(1 / 2)$, and the number of patents to the power of $(1 / 5)$ were used as dependent variables.

Table 16 summarizes the stepwise linear regression results using the number of new processes to the power of $(1 / 3)$ as the dependent variable for the specialized suppliers sub-sample. The number of topics pertaining to industry information was the only independent variable that met the criteria for inclusion into the regression model using the sub-sample comprised of specialized suppliers.

Table 16: Results of performing stepwise linear regression with number of new processes to the power of $(1 / 3)$ as the dependent variable using the sub-sample comprised of specialized suppliers

\begin{tabular}{|c|c|c|c|c|}
\hline $\begin{array}{c}\text { Model } \\
\text { summary }\end{array}$ & R & R Square & Adjusted R Square & Std. Error \\
\hline 1 & .882 & .777 & .750 & .482 \\
\hline
\end{tabular}

a Predictors: (Constant), number of topics pertaining to industry info

ANOVA
\begin{tabular}{|c|c|c|c|c|c|c|}
\hline Model & & Sum of Squares & df & Mean Square & F & Sig. \\
\hline 1 & Regression & 6.502 & 1 & 6.502 & 27.952 & .001 \\
\hline & Residual & 1.861 & 8 & .233 & & \\
\hline & Total & 8.363 & 9 & & & \\
\hline
\end{tabular}

a Predictors: (Constant), number of topics pertaining to industry info

b Dependent Variable: number of new processes $* *(1 / 3)$

c Selecting only cases for which type of company $=$ specialized suppliers 
Table 16: Continued

Coefficients

\begin{tabular}{|c|c|c|c|c|c|c|}
\hline & & $\begin{array}{c}\text { Unstandard. } \\
\text { Coefficients }\end{array}$ & & $\begin{array}{c}\text { Standard. } \\
\text { Coefficients }\end{array}$ & t & Sig. \\
\hline Model & & B & Std. Err & Beta & & \\
\hline $\mathbf{1}$ & (Constant) & -.965 & .473 & & -2.04 & .076 \\
\hline & $\begin{array}{c}\text { number of topics } \\
\text { pertaining to industry }\end{array}$ & .423 & .080 & .882 & 5.287 & .001 \\
\hline
\end{tabular}

a Dependent Variable: number of new processes**(1/3)

b Selecting only cases for which type of company $=$ specialized suppliers

Excluded Variables

\begin{tabular}{|c|c|c|c|c|c|c|}
\hline & & Beta In & $\mathbf{t}$ & Sig. & $\begin{array}{c}\text { Partial } \\
\text { Correlation }\end{array}$ & $\begin{array}{c}\text { Collinearity } \\
\text { Statistics }\end{array}$ \\
\hline Model & & & & & & Tolerance \\
\hline $\mathbf{1}$ & $\begin{array}{c}\text { number of topics } \\
\text { pertaining customers }\end{array}$ & .395 & 1.416 & .200 & .472 & .317 \\
\hline & $\begin{array}{c}\text { number of topics } \\
\text { pertaining competitors }\end{array}$ & .038 & .178 & .864 & .067 & .689 \\
\hline & $\begin{array}{c}\text { number of topics } \\
\text { pertaining company }\end{array}$ & -.029 & -.159 & .878 & -.060 & .946 \\
\hline & Total number of topics & .068 & .260 & .802 & .098 & .464 \\
\hline
\end{tabular}

a Predictors in the Model: (Constant), number of topics pertaining to industry info

b Dependent Variable: number of new processes**(1/3) 


\subsubsection{Results for the service company sub-sample}

For the service company sub-sample, no independent variables were included into the regression model when the number of products to the power of $(1 / 3)$, the number of processes to the power of $(1 / 3)$, and the number of services to the power $(1 / 2)$ were used as dependent variables.

Table 17 summarizes the stepwise linear regression results using the number of patents to the power of $(1 / 5)$ as the dependent variable for the service company sub-sample. The number of topics pertaining to customer intelligence information was the only independent variable that met the criteria for inclusion into the regression model using the sub-sample comprised of service companies.

Table 17: Results of performing stepwise linear regression with number of patents filed to the power of (1/5) as the dependent variable using the sub-sample comprised of service companies

\begin{tabular}{|c|c|c|c|c|}
\hline $\begin{array}{c}\text { Model } \\
\text { summary }\end{array}$ & R & R Square & Adjusted R Square & Std. Error \\
\hline $\mathbf{1}$ & .603 & .364 & .315 & .343 \\
\hline
\end{tabular}

a Predictors: (Constant), number of topics pertaining customers

ANOVA
\begin{tabular}{|c|c|c|c|c|c|c|}
\hline Model & & Sum of Squares & df & Mean Square & F & Sig. \\
\hline $\mathbf{1}$ & Regression & .874 & 1 & .874 & 7.440 & .017 \\
\hline & Residual & 1.526 & 13 & .117 & & \\
\hline & Total & 2.400 & 14 & & & \\
\hline
\end{tabular}

a Predictors: (Constant), number of topics pertaining to customer info

b Dependent Variable: number of new patents**(1/5)

c Selecting only cases for which type of company $=$ service companies 
Table 17: Continued

\section{Coefficients}

\begin{tabular}{|c|c|c|c|c|c|c|}
\hline & & $\begin{array}{c}\text { Unstandard. } \\
\text { Coefficients }\end{array}$ & & $\begin{array}{c}\text { Standard. } \\
\text { Coefficients }\end{array}$ & t & Sig. \\
\hline Model & & B & Std. Err & Beta & & \\
\hline $\mathbf{1}$ & (Constant) & 1.005 & .308 & & 3.262 & .006 \\
\hline & $\begin{array}{c}\text { number of topics } \\
\text { pertaining to } \\
\text { customers }\end{array}$ & -.128 & .047 & -.603 & -2.728 & .017 \\
\hline
\end{tabular}

a Dependent Variable: number of new patents**(1/5)

b Selecting only cases for which type of company $=$ service companies

\section{Excluded Variables}

\begin{tabular}{|c|c|c|c|c|c|c|}
\hline & & Beta In & $\mathbf{t}$ & Sig. & $\begin{array}{c}\text { Partial } \\
\text { Correlation }\end{array}$ & $\begin{array}{l}\text { Collinear. } \\
\text { Statistics }\end{array}$ \\
\hline Model & & & & & & Tolerance \\
\hline \multirow[t]{4}{*}{1} & $\begin{array}{c}\text { total number of } \\
\text { topics }\end{array}$ & .090 & .346 & .735 & .099 & .783 \\
\hline & $\begin{array}{l}\text { number of topics } \\
\text { pertaining to } \\
\text { industry }\end{array}$ & .105 & .436 & .671 & .125 & .895 \\
\hline & $\begin{array}{l}\text { number of topics } \\
\text { pertaining to } \\
\text { competitors }\end{array}$ & .066 & .283 & .782 & .081 & .975 \\
\hline & $\begin{array}{l}\text { number of topics } \\
\text { pertaining to } \\
\text { company }\end{array}$ & .050 & .217 & .832 & .063 & .977 \\
\hline
\end{tabular}

a Predictors in the Model: (Constant), number of topics pertaining to customer info

b Dependent Variable: number of new patents**(1/5)

\subsubsection{Summary of stepwise regression results}

This section summarizes the results obtained from the linear regression analysis of the relationship between innovation performance and number of competitive intelligence information topics used to make decisions about product, process and service introduction as well as patent filing. For the 45-company sample, results from the exploratory research study suggest that the number of information topics pertaining to 
customer information used to make decisions is positively related to the number of new processes the companies introduced.

For the new technology-based sub-sample, results suggest that:

- the number of information topics pertaining to customer information used to make decisions is positively related to the number of new processes introduced

- the number of information topics pertaining to company information used to make decisions is positively related to the number of new services introduced

For the specialized supplier sub-sample, results suggest that the number of topics pertaining to industry information is positively related to the number of new processes introduced.

For the service company sub-sample, results suggest that the number of topics pertaining to customer information is negatively related to the number of new patents introduced. 


\section{DISCUSSION OF RESULTS}

This chapter is organized into two parts. The first part discusses the results obtained when examining whether company type affects innovation performance. The second part of the chapter discusses the results obtained when examining the relationship between the number of topics companies used to make decisions about innovation and the innovation performance of small companies.

\subsection{Company type and innovation performance}

The results reported in the previous chapter failed to support Proposition 1a, "New technology-based companies and specialized suppliers introduce a larger number of new products and new processes than service companies." The means of new products and new processes introduced by companies in the three company types since June 2001 were not statistically significant at $\mathrm{P}<.10$. This result suggests that IRAP funded companies that see themselves as being service companies introduce new products and processes at the same rate that new technology-based companies and specialized suppliers do.

The results support Proposition 1b, "Service companies introduce a larger number of new services than new technology-based and specialized suppliers." The mean of the number of services introduced by service companies since June 2001 was greater than the means of the numbers of new services introduced by new technology-based companies and specialized suppliers. There was no significant difference in the number of new services 
introduced by new technology-based companies and specialized suppliers.

The results provide partial support to Proposition 1c, "New technology-based companies have a larger number of new patents than specialized suppliers and service companies." The results show that new technology-based companies file a larger number of patents than service companies. However, there was no statistical difference in the number of patents filed by new technology-based companies and specialized suppliers and in the number of patents filed by specialized suppliers and service companies.

The addition of the service company type has increased our understanding of small companies' innovation performances. The findings lend support to the conclusions made by Hoffman et al. (1998), Sirilli et al., (1998), and Weerawardena et al. (2002) that mixing product and service companies in the analysis of small company innovation can introduce significant biases.

The results reported in Chapter 5 support some of the results reported by Souitaris (2002) and not others. Based on a sample comprised of large companies, Souitaris (2002) concluded that (i) if innovation is measured by the number of new patents, new technology-based companies have a higher innovation performance than specialized suppliers and (ii) if innovation is measured by the number of new processes, there is no statistical difference in the innovation performance of specialized suppliers and new technology-based companies. The results of this thesis support these two results reported by Souitaris (2002). 
The results of this research did not support Souitaris' finding that if the number of new products measures innovation performance, new technology-based companies have a higher performance than specialized suppliers (Souitaris, 2002). The results reported in Chapter 5 suggest that there is no difference in the innovation performance of new technology-based companies and specialized suppliers when the number of new products is used to measure innovation performance.

\subsection{Innovation performance and intelligence information topics}

The results of this study provide partial support to Proposition 2, "The number of different intelligence information topics used by IRAP funded companies is positively related to their innovation performance." Table 18 summarizes the results of using stepwise linear regression to examine the relationship between innovation performance and the number of information topics used to make decisions about new product, process and service introduction as well as patent filings. 
Table 18: Results obtained by using stepwise regressions to examine the relationship between innovation performance and number of information topics used to make decisions about innovation

\begin{tabular}{|c|c|c|c|c|c|}
\hline \multirow{2}{*}{} & \multicolumn{5}{|c|}{$\begin{array}{c}\text { Information topics used to make decisions about new products, } \\
\text { processes, services and patents }\end{array}$} \\
\cline { 2 - 6 } & $\begin{array}{c}\text { Total } \\
\text { number } \\
\text { topics }\end{array}$ & $\begin{array}{c}\text { Number of } \\
\text { industry } \\
\text { topics }\end{array}$ & $\begin{array}{c}\text { Number of } \\
\text { customer } \\
\text { topics }\end{array}$ & $\begin{array}{c}\text { Number of } \\
\text { competitor } \\
\text { topics }\end{array}$ & $\begin{array}{c}\text { Number of } \\
\text { company } \\
\text { topics }\end{array}$ \\
\hline $\begin{array}{c}\text { Number of } \\
\text { products }\end{array}$ & $\mathrm{X}$ & $\mathrm{X}$ & $\mathrm{X}$ & $\mathrm{X}$ & $\mathrm{X}$ \\
\hline $\begin{array}{c}\text { Number of } \\
\text { processes }\end{array}$ & $\mathrm{X}$ & $\begin{array}{c}\text { specialized } \\
\text { suppliers }\end{array}$ & $\begin{array}{c}\text { sample and new } \\
\text { technology- } \\
\text { based } \\
\text { companies }\end{array}$ & $\mathrm{X}$ & $\mathrm{X}$ \\
\hline $\begin{array}{c}\text { Number of } \\
\text { services }\end{array}$ & $\mathrm{X}$ & $\mathrm{X}$ & $\mathrm{X}$ & $\mathrm{X}$ & $\begin{array}{c}(+) \text { for new } \\
\text { technology- } \\
\text { based }\end{array}$ \\
\hline $\begin{array}{c}\text { Number of } \\
\text { patents }\end{array}$ & $\mathrm{X}$ & $\mathrm{X}$ & $\begin{array}{c}(-) \text { for service } \\
\text { companies } \\
\text { companies }\end{array}$ & $\mathrm{X}$ & $\mathrm{X}$ \\
\hline
\end{tabular}

$\mathrm{X}-$ means no relationship between the variables in the corresponding row and column

The results summarized in Table 18 suggest that:

- the total number of topics IRAP funded companies used to make decisions about innovation is not related to the number of new products, processes, services and patents they introduced 
- the number of industry related topics specialized suppliers used to make decisions about innovation is positively related to the number of processes they introduced

- the number of customer topics new technology-based companies used to make decisions about innovation is positively related to the number of processes they introduced

- the number of competitor related topics that IRAP funded companies used to make decisions about innovation was not related to the number of new products, processes, and services they introduced or the number of patents they filed

- the number of company related topics new technology-based companies used to make decisions about innovation is positively related the number of services they introduced

The results of this research suggest that IRAP funded companies do not efficiently use competitive intelligence information for innovation purposes. These results support findings reported by Freel (2003), Nelson (2000), Oerlemans et al. (1998) and contradict the results reported by Souitaris (2002).

There are at least two explanations for the finding that the total number of topics and the number of competitor related topics used to make decisions about innovation do not affect the innovation performance of IRAP funded companies. First, IRAP funded companies make decisions about new products, processes, services and patents relying mainly on their own internal logic and results of their own research and development 
efforts without using competitive intelligence on competitors as a reference point. Second, IRAP funded companies lack the resources and capabilities required to acquire and process external information, particularly information about competitors, for the purpose of introducing new products, processes, services and patents.

The finding that there is a positive relationship between the total number of new processes introduced by IRAP funded firms and the number of customer related topics used to innovate is an interesting finding. This is the only statistically significant relationship found to hold for the full sample. When this relationship was tested for each sub-sample, a statistically significant relationship was only found for new technologybased companies. This result contradicts results reported by Freel (2003). Freel reported that customer and, more generally, external innovation-related interactions are expected to be of limited importance for process innovation in both, new technology-based firms and specialized suppliers.

The number of new processes introduced by IRAP funded companies was found to be positively related to the number of industry related topics (e.g., specialized suppliers) and the number of customer related topics (e.g., new technology-based companies) used to innovate. The number of new processes introduced was not related to competitor and company related topics.

Previous studies (Weerawardena, 2003; Kaplan, 2000; Morris et al., 1996; Windrum et al., 1999; Martin et al., 1993; Coyne, 1993; Easingwood et al., 1989) highlight the 
importance of services in both service and product companies. In this study, the number of new services introduced by new technology-based companies was found to be positively related to the number of company related topics used to innovate. This suggests that new technology-based companies commercialize services originally developed to meet their own needs.

Interaction with customers has been previously found to be an important factor for service companies (Johne et al., 1998, Sirilli et al., 1998, Evangelista, 2000). The results obtained in this research show that the number of patents filed by service companies was negatively related to the number of customer related topics used to innovate. This is a finding that needs to be further investigated in future studies. The data does not allow us to shed light as to the reasons for this result. 


\section{CONCLUSIONS, LIMITATIONS AND SUGGESTIONS \\ FOR FURTHER RESEARCH}

\subsection{Conclusions}

The objective of this thesis was to examine how company type and the number of intelligence information topics that IRAP funded companies use to make decisions about new products, processes, services and patents affect their innovation performance.

IRAP funded service companies introduce more new services and as many new products and processes as IRAP funded new technology-based companies and specialized suppliers do. This is an interesting result because it highlights the importance of service companies to the success of the IRAP program.

IRAP funded new technology-based companies file as many patents as do IRAP funded specialized suppliers. This is another interesting result that appears to be unique to small companies. Previous researchers have found that the number of patents filed by new technology-based companies is greater than the number of patents filed by specialized suppliers (Souitaris, 2002).

IRAP funded companies may not have the resources, processes or value systems required to use different competitive intelligence information when making decisions on innovation or may rely more on their own internal logic than on external information. 
Thus, the total number of intelligence topics IRAP companies use to make decisions about innovation is not associated with the number of new products, processes, services and patents introduced into the marketplace.

The positive relationship between the number of new services introduced by new technology-based firms and the number of company related information topics used suggests that these companies try out services internally first and then proceed to commercialize them to other companies with similar needs for these services.

The following conclusions can be drawn:

- the evaluation of the innovation performance of IRAP's clients needs an appropriate company taxonomy

- IRAP's investments in tools and mechanisms to enable small companies' access to a broader range of competitive intelligence information are not justified

- IRAP investments may be oriented to the development of small companies' capabilities to process and analyze CI information with a focus to develop new products

- product oriented companies can enhance their innovation capacity to develop new processes and services

- service companies possess a strong innovation potential and are important for IRAP's success 


\subsection{Limitations}

This study has two main limitations. The first limitation is that this research focused on a distinct sample of small companies, those that are funded by the IRAP. It cannot be argued that the sample drawn for this study reflects the population of small companies in Canada that innovate. Many small companies do not qualify to receive IRAP funding yet they do innovate. Thus, the findings of this research cannot be generalized to the entire population of small companies in Canada that innovate.

The second limitation is that the information categorization proposed by Gordon (2002) that was used in this research is an attribute-based categorization. It emphasizes the number of information types and not the circumstances in which the particular information types were used. Christensen et al. (2003) and other researchers argue that a better categorization is one based on the use of information and not on its attributes.

\subsection{Suggestions for Future Research}

Three areas for future research are suggested. First, a future study could first develop a categorization of the competitive intelligence information based on the circumstances in which the particular information is used (Christensen et al., 2003), and then use the taxonomy to examine the relationship between competitive intelligence information and innovation performance of small companies. 
Second, future studies can investigate how geography affects the innovation performance of IRAP funded companies.

Third, a future study can consider a broader range of companies such as ones that are not funded by the IRAP. The choice of IRAP funded companies biases the research sample towards more technologically oriented company types. In this sense the technology based company taxonomy used in this study is perfectly justified. A more general approach including a broader variety of small companies would require a different company taxonomy. An example of a non technologically based taxonomy can be found in a recent study by St-Pierre et al, 2003. It provides a three dimensional model for the classification of small companies based on i) export, ii) innovation and iii) market development autonomy. 


\section{REFERENCES}

Ali, A., Swiercz, R. 1991. Company size and export behavior: lessons from the Midwest, Journal of Small Business Management, 4: 71-78.

Achrol, R. 1997. Changes in the theory of inter-organizational relations in marketing: toward a network paradigm, Journal of the Academy of Marketing Science, 25: 56-71.

Amit, R., Schoemaker, P. 1993. Strategic assets and organizational rent, Strategic Management Journal, 14: 33-46.

Ashton, W., Kalvans, R. 1997. An introduction to technical intelligence in business, in Ashton, W., (Ed.) Keeping Abreast of Science and Technology: Technical Intelligence in Business: 5-22. Columbus, OH: Battelle Press.

Audet, J. 2003. La Veille Stratégique chez les PME de Haute Technologie: une Etude de Cas par Comparaisons Inter-sites, Cahier de recherche CR-02-03, Institut de recherche sur les PME, Université du Québec a Trois Rivière, http://www.uqtr.ca/INRPME/pdf/0203-Audet.pdf, last visited July 15, 2003.

Bommer, M, Jalajas, D. 2004. Innovation sources of large and small technology-based companies, IEEE Transactions on Engineering Management, 51: 13-18.

Broome, P. 2001. Making competitive intelligence work for the small businesses, in

Fisher, C. and Bkenkhorn, D. (Eds.), Managing Frontiers in Competitive Intelligence, Westport, CT: Quorum books. 
Brouard, F. 2002. La Veille Stratégique, un Outil Pour Favoriser l'Innovation au

Canada, Conférence économique 2002 de Statistique Canada, http://www.statcan.ca/francais/conferences/economic2002/pdf/3E.Brouard f.pdf, last visited, April 6, 2004.

Calof, J, Brouard, F. 2004. Competitive intelligence in Canada, Journal of Competitive Intelligence and Management, 2: 1-21.

Calof, J. 2002. Competitive Intelligence Handbook, Food Bureau, Agriculture and AgriFood Canada. http://www.agr.gc.ca/fod/industryinfo/ci handbook_e.pdf, last visited 16 April, 2004.

Calof, J., W. Skinner. 1998. La veille concurrentielle: le meilleur des mondes pour les gestionnaires, Optimum, La revue de gestion du secteur public, 28: 42-47.

Carrier, C. 1994. Intrapreneurship in large companies and SMEs: a comparative study, International Small Business Journal, 12: 54-60.

Chen, M.-J., Hambrick, D. 1995. Speed, stealth, and selective attack: how small companies differ from large companies in competitive behavior, Academy of Management Journal, 38: 453-482.

Christensen, C., Raynor, M. 2003. The Innovator's Solution: Creating and Sustaining Successful Growth, Harvard Business School Press, Chapter 3. 
Christensen, P. 1991. The small and medium-sized exporters' squeeze: empirical evidence and model reflections, Entrepreneurship \& Regional Development, 3: 49-65.

Cobbenhagen, J. 2000. Successful Innovation: Towards a New Theory for the Management of Small and Medium-sized Enterprises, Cheltenham, Edward Elgar Publishing.

Cohen, M., Levinthal, D. 1990. Absorptive capacity: a new perspective on learning and innovation, Administrative Science Quarterly, 35: 128-152.

Coyne, K. 1993. Achieving a sustainable service advantage, Journal of Business Strategy, 14: 3-10.

Deszca, G., Munro, H., Noori, H. 1999. Developing breakthrough products: challenges and options for market assessment, Journal of Operations Management, 17: 613-630.

Downs, G., Mohr, L. 1976. Conceptual issues in the study of innovation, Administrative Science Quarterly, 21: 700-714.

Easingwood, C., Mahajan, V. 1989. Positioning of financial services for competitive advantage, Journal of Product Innovation Management, 6: 207-219.

Edvardsson, B., Olsson, J. 1996. Key concepts for new service development, Service Industries Journal, 16: 140-164. 
Evangelista, R. 2000. Sectoral patterns of technological change in services, Economics of Innovation and New Technology, 9: 183-221.

Ferrier, W. 2001. Navigating the competitive landscape; the drivers and consequences of competitive aggressiveness, Academy of Management Journal, 44: 858-877.

Freel, M. 2003. Sectoral patterns of small company innovation, networking and proximity, Research Policy, 32: 751-770.

Garson, G. 2004, An Online Textbook, North Carolina State University http://www2.chass.ncsu.edu/garson/pa765/statnote.htm, last visited November 20, 2004.

Gemunden, H., Heydebreck, P., Herden, R. 1992. Technological interweavement: a means of achieving innovation success, $R \& D$ Management, 22: 359-376.

Gordon, I. 1998. Relationship Marketing: New Strategies, Techniques and Techniques to Win the Customers You Want and Keep them Forever, Toronto, John Wiley \& Sons.

Gordon, I. 2002. Competitor Targeting, Winning the Battle for Market and Customer Share, Toronto, ON, Canada: John Wiley \& Sons.

Hadjimanolis, A. 2002. An investigation of innovation antecedents in small companies in the context of a small developing country, $R \& D$ Management, 30: 235-245.

Hagedoorn, J., Cloodt, M. 2003. Measuring innovative performance: is there an advantage in using multiple indicators?, Research Policy, 32: 1365-1379. 
Herring, J. 1999. Key intelligence topics: a process to identify and define intelligence needs, Competitive Intelligence Review, 10: 4-14.

Herring, J. 2002. KITs revisited: their use and problems, SCIP Online, 1, http://www.imakenews.com/scip2/e article000069099.cfm, last visited Nov. 28, 2004.

Hoffman, K., Praejo, M., Bessant, J. 1998. Small firm's R\&D, technology and innovation in the UK: a literature review, Technovation, 18: 39-56.

Industrial Research Assistance Program. 2002. Investing in Innovation: NRC-IRAP's 2003-2008 Strategy to Stimulate Canadian SME Success, http://irap-pari.nrccnrc.gc.ca/english/strategicdirections e.html, last visited November 27, 2002.

Johanson, J, Vahlne, J. 1993. The internationalization process of the firm: a model knowledge development and increasing foreign market commitments, in Buckley, P. and Ghauri, P. (Eds.), The Internationalization of the Firm: a Reader, London, UK: Academic Press Ltd.

Johne, A., Storey, C. 1998. New service development: a review of literature and annotated bibliography, European Journal of Marketing, 32: 184-251.

Johnson, A. 2002. The Top 12 Priorities for Competitive Intelligence, Aurora WDC,

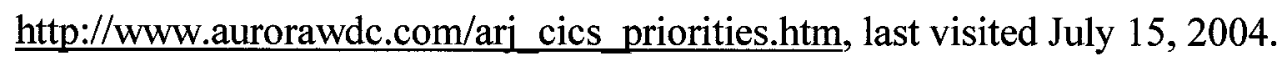


Julien, P.-A., Toulouse, J.-M., Ramangalahy, C., Morin, M., Lachance, R. 1998. Information Behaviour, Competitiveness and Performance in Small and Medium-sized Export Businesses, Cahier de recherche CR-98-13, Institut de Recherche sur les PME, Université du Québec a Trois Rivière, http://www.uqtr.uquebec.ca/inrpme/pdf/98-13Julien.pdf, last visited November 26, 2004.

Kaplan, S. 2000. Innovating professional services, Consulting to Management, 11: 30-34.

Katila, R. 2002. New product search over time: past ideas in their time, Academy of Management Journal, 45: 996-1010.

Khan, A., Manopichetwattana, V. 1989. Innovative and non-innovative small companies: types and characteristics, Management Science, 35: 597-606.

Lapointe, A. 1995, Nouvelle économie et gestion, Gestion, 20 : 52-56.

Lefebvre, E., Lefebvre, L. and Harvey, J. 1993. Competing internationally through multiple innovative efforts, $R \& D$ Management, 23: 227-237.

Lefebvre, L., Mason, R., Lefebvre, E. 1997. The influence prism in SMEs: the power of CEOs' perceptions on the technology policy and its organisational impacts, Management Science, 43: 856-878.

Lengnick-Hall, C. 1992. Innovation and competitive advantage: what we know and what we need to learn, Journal of Management, 18: 399-429. 
Lehtimaki, A. 1991. Management of the innovation process in small companies in Finland, IEEE Transactions on Engineering Management, 38: 120-126.

MacPherson, A. 1997. The contribution of external service inputs to the product development efforts of a small manufacturing companies, $R \& D$ Management, 27: 127144.

MacPherson, A. 1992. Innovation, external technical linkage and small company commercial performance: an empirical analysis from Western New York, Entrepreneurship and Regional Development, 4: 165-183.

Madhok, A. 1996. Local markets, global education: the company in the international knowledge economy, Management International, 1: 95-99.

Martin, C., Horne, D. 1993. Services innovation: successful versus unsuccessful companies, International Journal of Service Industry Management, 4: 49-65.

Miller, D., Chen, M. 1996. The simplicity of competitive repertories: An empirical analysis, Strategic Management Journal: 17: 419-439.

Miller, D., Friesen, P. 1984. Organisations: A Quantum View, Englewood Cliffs, NJ: Prentice-Hall.

Mohr, L. 1969. Determinants of innovation in organizations, American Political Science Review, 63: 111-126. 
Morris, T., Westbrook, R. 1996. Technical innovation and competitive advantage in retail financial services: a case study of change and industry response, British Journal of Management, 7: 45-61.

Namiki, N. 1988. Export strategy for small business, Journal of Small Business Management, 26: 21-37

Nelson, R. 2000, National innovation systems, in Acs, Z. (Ed.), Regional Innovation, Knowledge and Global Change, London, Pinter: 11-26.

Noori, H., McWilliams, B., Deszca, G., Munro, H. 2001. New product development and competitive intelligence, in Fisher, C. and Bkenkhorn, D. (Eds.), Managing Frontiers in Competitive Intelligence, Westport, CT: Quorum books: 159-172.

Oerlemans, L., Meeus, M., Boekema, F. 1998. Do networks matter for innovation? The usefulness of the economic network approach in analyzing innovation, Tijdschrift voor Economische en Sociale Geografie, 89: 298-309.

Organization for Economic Co-operation and Development. 1997. OSLO Manual, The Measurement of Scientific and Technological Activities, Proposed Guidelines for Collecting and Interpreting Technological Innovation Data, Second Edition, European Commission, Eurostat, http://www.oecd.org/dataoecd/35/61/2367580.pdf, last visited Nov. 28, 2004.

Pavitt, K. 1984. Sectoral patterns of technical change: towards a taxonomy and a theory, Research Policy, 13: 343-373. 
Pavitt, K., Robson, M., Townsend, J. 1989. Technological accumulation, diversification and organization in UK companies, Management Science, 35: 81-99.

Porter, M. 1980. Competitive Strategy: Techniques for Analyzing Industries and Competitors, New York: Free Press.

Porter, M. 1985. Competitive Advantage: Creating and Sustaining Superior Performance, New York: Free Press.

Porter, M. 1990. The Competitive Advantage of the Nations, New York: Free Press.

Canadian Federation of Independent Business, Canadian Manufacturers and Exporters \&

RBC Financial Group, 2002. The Path to Prosperity: Canada's Small-and Medium-Sized Enterprises, www.rbc.com/newsroom, last visited November 28, 2004.

Reid, S. 1984. Information acquisition and export entry decisions in small companies, Journal of Business Research, 12: 141-157.

Rothwell, R. 1974. SAPPHO updated: project SAPPHO phase II, Research Policy, 3: $258-291$.

Rothwell, R. 1977. The characteristics of successful innovators and technically progressive companies (with some comments on innovation research), $R \& D$ Management, 7: 191-206. 
Rothwell, R. 1989. SMEs' intercompany relationships and technological change, Entrepreneurship and Regional Development, 1: 65-81.

Rothwell, R., Dodgson, M. 1991. External linkages and innovation in small and mediumsized entrepreneurs, R\&D Management, 21: 125-137.

Rothwell, R. 1992. Successful industrial innovation: critical factors for the 1990 s, $R \& D$ Management, 22: 221-239.

Rouach, D., Santi, P. 2001. Competitive Intelligence adds value: five intelligence attitudes, European Management Journal, 19: 552-559.

Saviotti, P., Metcalfe, J. 1984. A theoretical approach to the construction of technological output indicators, Research Policy, 13: 141-151.

Savioz, P. 2004. Technology Intelligence, Concept Design and Implementation in Technology-based SMEs, Palgrave Macmillan.

Seringhaus, R. 1987. The role of information assistance in the small firm's export involvement, International Small Business Journal, 5: 26-36.

Sirilli, G., Evangelista, R. 1998. Technological innovation in services and manufacturing: results from Italian surveys, Research Policy, 27: 881-899.

Souitaris, V. 1999. Research on the determinants of technological innovation. A contingency approach., International Journal of Innovation Management, 3: 287-305. 
Soutaris, V. 2002. Technological trajectories as moderators of firm-level determinants of innovation, Research Policy, 31: 877-898.

St-Pierre, J., Audet, J., Mathieu, C. 2003. Les nouveaux modèles d'affaires des PME manufacturières : une étues eplorateure, UQTR-INRPME, January 2003, http://www.uqtr.ca/inrpme/pdf/Rapport final janvier2003.pdf

Tidd, J., Bessant, J, Pavitt, K. 2001. Managing innovation - Integrating Technological, Market and Organizational Change, Second Edition, Chichester: John Wiley \& Sons.

Verhoeven, W. 1988. The export performance of small and medium-sized enterprises in the Netherlands, International Small Business Journal, 6: 20-33.

Weerawardena, J., McColl-Kennedy, J. 2002. New service development and competitive advantage: a conceptual model, Australian Marketing Journal, 10: 13-23.

Weerawardena, J. 2003. The role of marketing capability in innovation-based competitive strategy, Journal of strategic marketing, 11: 15-35.

Weerawardena, J. 2004. Small Company Competitive Strategy: A Conceptual Model and Research Propositions, Research report, Small Business Advancement National Center, University of Central Arkansas, College of Business Administration, United States, Arkansas.

Windrum, P., Tomlinson, M. 1999. Knowledge intensive services and international competitiveness: a four-country comparison, Technology Analysis and Strategic Management, 11: 391-408. 
Wolfe, R. 1994. Organizational innovation: review, critique and suggested research directions, Journal of Management Studies, 31: 405-431. 


\section{Appendix A. The Industrial Research Assistance Program}

The National Research Council's Industrial Research Assistance Program (NRC-IRAP) is Canada's premier innovation assistance program for small and medium-sized Canadian enterprises (SMEs). It is a vital component of the NRC, a cornerstone in Canada's innovation system, regarded world-wide as one of the best programs of its kind.

As a key enabler within Canada's innovation system, NRC-IRAP provides Canadian SMEs with value-added technological and business advice, financial assistance and a range of other innovation assistance. NRC-IRAP helps SMEs realize their full potential, turning knowledge and innovation into strategic opportunities, jobs and prosperity for all Canadians. In order to receive help from IRAP companies need to meet three criteria:

- to be incorporated and profit-oriented

- to have fewer than 500 employees

- to have the desire to enhance their innovation capability

\section{IRAP's Advisory Services}

NRC-IRAP uses a field staff of professionals, widely recognized for their scientific, technical, business expertise and knowledge of the innovation process to provide its clients with value-added advice and financial services. NRC-IRAP's success stems from a long track record of service and the outstanding, highly skilled people that deliver the program at the local level. 
Industrial Technology Advisors (ITAs) deliver customized services to NRC-IRAP clients through a national network of some 260 ITAs, located in 90 communities across Canada. They coach a client project through all stages of the innovation process, providing technical advice, referrals and other innovation services as needed.

\section{IRAP's Financial Services}

- Contributions for R\&D Activities

- NRC-IRAP Technology Partnerships Canada (IRAP-TPC)

- Youth Employment Strategy Programs

\section{Contributions for R\&D Activities}

IRAP provides non-repayable contributions to Canadian small and medium-sized enterprises (SMEs) on a cost-shared basis for research and pre-competitive development technical projects, upon assessment of a project and firm by a team of ITAs. IRAP's partner organizations also receive contributions to provide technical and research assistance to Canadian SMEs.

\section{NRC-IRAP Technology Partnerships Canada (IRAP-TPC)}

The IRAP-Technology Partnerships Canada (TPC) program provides Canadian SMEs with repayable financial assistance for projects at the pre-commercialization stage. Firms use these funds to develop technology for new or significantly improved products, processes or services, as well as to support initial demonstration and pilot projects. IRAP delivers the IRAP-TPC program on behalf of Technology Partnerships Canada/Industry 
Canada.

Youth Employment Strategy Programs

NRC-IRAP's Internship Program with Innovative Small and Medium-sized Enterprises and Collaborative Research Internships Program provide firms with support to hire postsecondary graduates. Both firms and graduates benefit from these programs: firms benefit from the graduate's expertise in a diverse variety of disciplines and graduates gain valuable work experience that will help open the doors for future employment. NRCIRAP delivers this youth initiative on behalf of the Government of Canada's Youth Employment Strategy (YES) Programs with funds from the Department of Human Resources and Skills Development a (HRSD).

IRAP's financial assistance is one component of a complete service package that enables SMEs to validate and develop innovative ideas. Financial assistance is available upon an assessment of the project and of the firm by an Industrial Technology Advisor and upon availability of funds. 


\section{Appendix B. Definitions of new product, new process and new service}

The definitions of new product, new process and new service given here are derived from the OSLO manual (Organization for Economic Co-operation and Development, 1997).

\section{New product}

For the purpose of this research, a new product refers to completely new or significantly improved products.

A technologically new product is a product whose technological characteristics or intended uses differ significantly from those of previous products. Such innovations can involve radically new technologies, can be based on combining existing technologies in new uses, or can be derived from the use of new knowledge.

\section{Examples:}

The first microprocessors and videocassette recorders were examples of technologically new products of the first kind, using radically new technologies. The first portable cassette player, which combined existing tape and mini-headphone techniques, was a technologically new product of the second type, combining existing technologies in a new use. In each case the overall product had not existed before.

A technologically improved product is an existing product whose performance has been significantly enhanced or upgraded. A simple product may be improved (in terms of 
better performance or lower cost) through use of higher-performance components or materials, or a complex product which consists of a number of integrated technical subsystems may be improved by partial changes to one of the sub-systems.

\section{Examples:}

The substitution of plastics for metals in kitchen equipment or furniture is an example of the use of higher performance components. The introduction of ABS braking or other sub-system improvements in cars is an example of partial changes to one of a number of integrated technical sub-systems.

\section{New process}

A technologically new process consists in the adoption of technologically new or significantly improved production methods, including methods of product delivery. These methods may involve changes in equipment, or production organization, or a combination of these changes, and may be derived from the use of new knowledge. The methods may be intended to produce or deliver technologically new or improved products, which cannot be produced or delivered using conventional production methods, or essentially to increase the production or delivery efficiency of existing products.

\section{New service}

A service is considered to be technologically new when its characteristics and modalities of use are either completely new or have been significantly improved from a qualitative point of view, or in terms of their performance and technologies used. The introduction of 
a technologically innovative service can require the use of radically new technologies, a combination of pre-existing technologies or new knowledge. A service consisting of a set of a number of integrated technical sub-systems can be technologically improved by changing one or more of the sub-systems.

\section{Examples:}

Wholesaling of machinery, equipment and supplies. Creation of web sites on the Internet, where new services such as product information and various support functions can be offered to clients free of charge.

Banks. The introduction of smart cards and multipurpose plastic cards.

Software consultancy and supply companies. The introduction of new multimedia software applications that can be used for educational purposes and thus eliminate the need for a real life human instructor. 


\section{Appendix C. Intelligence information topics}

\section{Category 1: Industry}

- Evolution, ongoing changes in, or projected future state of the industry

- Particular competitive actions/responses among some of company's existing competitors

- Industry's current market/segment share in all product-market intersections

- Bargaining power of suppliers

- Threat of new product/service substitutes including emerging technologies developments that may affect company's existing products or services

- Threat of newly appearing competitors that may cause unexpected changes in current market/segment and customer shares

- Bargaining power of buyers

- Threat of takeover/ownership changes in company's competitors and partners that may cause the company to take actions running counter to its long-term interests

- Threat of legislative, political or social actions weakening the industry or making it receive negative attention by special interest, political or lobby groups and social critics

- Ongoing or anticipated production, marketing or management globalization processes

\section{Category 2: Customer}

- Companies and customers that are the most profitable for the company?

- Company's profit potential from other customers in the industry as compared to 
company's existing customers?

- Present state of company's relationship with existing customers - how company's existing customers view the company, its services, its human resource, technological and other capabilities, both in absolute terms and relative to company's competitors?

- Main initiatives and areas of spending company's customers are likely to undertake in the future.

- Company's current customer mix - which are the customers the company will focus on, invest in or just ignore?

- Competitors' positions relative to company's existing customers

- Amenability of company's important customers regarding business relationships with other companies and with the company itself in particular.

- Nature of company's important customers' bonding - what are the main values in the type of relationship the company offers?

- Customers' purchase decision making process - what are the main criteria by which the company and its competitors are assessed by specific customers?

\section{Category 3: Competitor}

- History and evolution of each of company's competitors in terms of articulated and manifested business mission, objectives and strategic directions

- General business profile of each of company's competitors

- Competitive forces and pressures presently acting upon company's competitors 
- Distinctive capabilities of competitor companies in terms of people, processes technologies, knowledge and competitive intelligence

- Dependency on key accounts, key people, customers, suppliers, regions and financial institutions

- Competitors' innovation capacity in terms of ability to introduce new products, processes, services and patents

- State of competitors' finances, their current performance and potential

- Competitors' technology including their in-house R\&D capabilities as well as their ability to adopt external advanced technology solutions

- Competitors' production in terms of current and potential capacity and quality

- Competitors' marketing capabilities

- Competitors sales force

\section{Category 4: Company}

- Company's history and roots

- Company's potential maximum achievements

- Company's distinctive capabilities and weaknesses

- Company's best customers' attraction relative to company's competitors

- Competitor customers' attraction/repulsion relative to the company

- Company's ability to deal with worse customers

- Company's ability to change faster than its competitors

- Company's ability to learn

- Company's ability to "unlearn" - undoing the people, process, technology and 
knowledge that were once appropriate but are now holding the company back.

- Company's current focus and priorities

- Company's ability to react to sudden changes in the competitive environment

- Company's competitive intelligence and counter-intelligence processes and capabilities 


\title{
Appendix D. Questionnaire
}

\section{English version}

\author{
Competitive Intelligence Information and Innovation Performance \\ of IRAP Funded Companies
}

A research study performed by

Dr. Stoyan Tanev, stoyan.tanev@vitesse.ca, Tel. 613-746-3595 x228, Fax 613-746-6653,

Supervisor: Dr. A. J. Bailetti, Dept. of System and Computer Engineering, Carleton

University, Tony.Bailetti@sce.carleton.ca, Tel: +1 613 520-2600 ext. 8398

within the framework of a joint project between

Telecommunications Technology Management Program,

Department of Systems and Computer Engineering, Carleton University, Ottawa

Industrial Research Assistance Program (IRAP), NRC

Canada Institute for Scientific and Technical Information (CISTI), NRC

Vitesse Re-Skilling ${ }^{\text {TM }}$ Canada, Ottawa

This questionnaire is for a research study that is part of a thesis for the degree of Master of Engineering in Telecommunication Technology Management (TTM), Department of Systems and Computer Engineering, Carleton University, Ottawa. The objective of the thesis is to examine how company type and the intelligence information used to make new product, process, service and patent decisions affect the innovation performance of small Canadian companies funded by the Industrial Research Assistance Program at the National Research Council of Canada.

It takes less than 15 minutes to complete the questionnaire. It does not require the disclosure of sensitive data. The questionnaire will be delivered and collected through IRAP's Industrial Technology Advisers (ITA). All respondents and companies will be kept anonymous. Please answer all questions and return the filled questionnaire to the ITA that has initially contacted you. You can fill out the questionnaire electronically by using the Microsoft Word file. All the necessary data you have to input is numerical. Please input the data in the grey boxes, fro example: 4 . To answer some of the questions you need check one of two boxes: " $\square$ Yes" or " $\square$ No". This can be done by clicking on the preferred box. Alternatively, you can print the questionnaire, fill it out by hand, and send it by fax to the corresponding ITA.

The time and effort you take to participate in this research study is appreciated.

For any questions you can anonymously contact Dr. Stoyan Tanev, Tel. 613-746-3595 x 228, Fax. 613-746-6653, stoyan.tanev@,vitesse.ca.

Thank you very much for your collaboration. 


\section{USEFUL DEFINITIONS}

\section{New product}

For the purpose of this research, a new product refers to completely new or significantly improved products. A new product is a product whose technological characteristics or intended uses differ significantly from those of previous products. It can involve radically new technologies, can be based on combining existing technologies in new uses, or can be derived from the use of new knowledge.

Examples of new products: The first microprocessors and videocassette recorders were examples of technologically new products using radically new technologies. The first portable cassette player, which combined existing tape and mini-headphone techniques, was a technologically new product combining existing technologies in a new use. In each case the overall product had not existed before.

An improved product is an existing product whose performance has been significantly enhanced or upgraded. A simple product may be improved (in terms of better performance or lower cost) through use of higher-performance components or materials, or a complex product which consists of a number of integrated technical sub-systems may be improved by partial changes to one of the sub-systems.

Examples of improved products: The substitution of plastics for metals in kitchen equipment or furniture is an example of the use of higher performance components. The introduction of $A B S$ braking or other sub-system improvements in cars is an example of partial changes to one of a number of integrated technical sub-systems.

\section{New process}

A new process consists in the adoption of technologically new or significantly improved production methods, including methods of product delivery. These methods may involve changes in equipment, or production organization, or a combination of these changes, and may be derived from the use of new knowledge. The methods may be intended to produce or deliver technologically new or improved products, which cannot be produced or delivered using conventional production methods, or essentially to increase the production or delivery efficiency of existing products.

\section{New service}

A service is considered to be new when its characteristics and modalities of use are either completely new or have been significantly improved from a qualitative point of view, or in terms of their performance and technologies used. The introduction of a technologically new service can require the use of radically new technologies, a combination of pre-existing technologies or new knowledge. A service consisting of a set of a number of integrated technical sub-systems can be technologically improved by changing one or more of the sub-systems.

Examples of new services: Creation of web sites on the Internet, where new services such as product information and various support functions can be offered to clients free of charge. The introduction of smart and multipurpose plastic banking cards. 


\section{Please answer the following questions.}

1. Which is the year of incorporation of your company?

\section{Answer:}

2. What was the approximate number of your company's employees in the last 5 years?

Year:

2000

2001

2002

2003

2004

Employees:

3. Is your company a service company? Please select one option.

$\square$ Yes $\quad \square$ No

If your answer is "Yes", please continue with answering the questions on the next page. If not, please answer the next question.

4. What are the main sources of your company's technology? Please select one option.
Mostly external
Mostly internal

If your answer is "Mostly external", please continue with answering the questions on next page. If not, please answer the next question.

5. What is your company's technology-based on? Please select one option.

Mostly internal R\&D and/or appropriation of academic research results

$\square$ Mostly internal engineering design and/or collaboration with lead users

Please continue answering the questions on next page. 
6. Since June 2001, did your company make decisions on new products, processes services or patents based on information about:

- the evolution, ongoing changes in, or projected future state of your industry?

$$
\square \text { Yes } \square \text { No }
$$

- particular competitive actions/responses among some of your existing competitors?

$\square$ Yes $\square$ No

- industry's present market/segment share in all product-market intersections?

$\square$ Yes $\quad \square$ No

- the bargaining power of your and your competitors' suppliers?

$\square$ Yes $\square$ No

- threats of new product/service substitutes including emerging technologies that may affect your existing products or services?
$\square$ Yes
$\square$ No

- threats of newly appearing competitors that may cause unexpected changes in your industry's current market/segment and customer shares?

$\square$ Yes $\quad \square$ No

- the bargaining power of your and your competitors' buyers?

$\square$ Yes $\square$ No

- threats of takeover/ownership changes in your competitor and partner companies that may cause your company to take actions running counter to its long-term interests?
$\square$ Yes
$\square$ No

- threats of legislative, political or social actions weakening your industry or making it receive negative attention by special interest, political or lobby groups and social critics?

$\square$ Yes $\square$ No

- ongoing or anticipated production, marketing or management globalization processes relative to your industry?

$\square$ Yes $\quad \square$ No


7. Since June 2001, did your company make decisions on new products, processes services or patents based on information about:

- the companies and customers that are the most profitable for your company?

$\square$ Yes $\quad \square$ No

- your company's profit potential from other customers in the industry relative to your existing customers?

$\square$ Yes $\quad \square$ No

- the present state of your relationship with existing customers the way your existing customers view your company, its services, its human resource, technological and other capabilities, both in absolute terms and relative to your competitors?

$\square$ Yes $\quad \square$ No

- the main initiatives and areas of spending your customers are likely to undertake in the future?

$\square$ Yes $\quad \square$ No

- your current customer mix - the customers your company will focus on, invest in or just ignore?

$\square$ Yes $\quad \square$ No

- your competitors' positions relative to your existing customers?

$\square$ Yes $\quad \square$ No

- the amenability of your most important customers regarding business relationships with other companies and in particular to your company?

$\square$ Yes $\quad \square$ No

- the nature of your most important customers' bonding - the main values for them in the type of relationship your company offers?

$\square$ Yes $\quad \square$ No

- your customers' purchase decision making process - the main criteria by which your company and its competitors are assessed by specific customers?

$\square$ Yes $\quad \square$ No 
8. Since June 2001, did your company make decisions on new products, processes services or patents based on information about:

- the history and evolution of each of your competitors in terms of articulated and manifested business mission, objectives and strategic directions?
$\square$ Yes
$\square$ No

- the general business profile of each of your competitors?
$\square$ Yes
$\square$ No

- the competitive forces and pressures presently acting upon your competitors?
Yes
No

- the distinctive capabilities of your competitors in terms of people, processes technologies, knowledge and competitive intelligence?
$\square$ Yes
No

- your competitors' dependency on key accounts, key people, customers, suppliers, regions and financial institutions?

$\square$ Yes $\square$ No

- your competitors' innovation capacity in terms of ability to introduce new products, processes, services and patents?
$\square$ Yes
No

- the state of your competitors' finances, their current performance and potential?

$\square$ Yes

No

- your competitors' technology including their in-house R\&D capabilities as well as their ability to adopt external advanced technology solutions?
$\square$ Yes
No

- your competitors' production in terms of current and potential capacity and quality?

$\square$ Yes $\quad \square$ No

- your competitors' marketing capabilities?
$\square$ Yes
$\square$ No

- your competitors sales force?

$\square$ Yes $\square$ No


9. Since June 2001, did your company make decisions on new products, processes services or patents based on information about:

- your company's history and roots?

$\square$ Yes $\square$ No

- your company's potential maximum achievements?

$\square$ Yes $\quad \square$ No

- your company's distinctive capabilities and weaknesses?

$\square$ Yes $\quad \square$ No

- your company's best customers' attraction relative to company's competitors?

$\square$ Yes $\quad \square$ No

- your competitor customers' attraction/repulsion relative to your company?

$\square$ Yes $\square$ No

- your company's ability to deal with its worse customers?

$\square$ Yes $\square$ No

- your company's ability to change?

$\square$ Yes $\quad \square$ No

- your company's ability to learn?

$\square$ Yes $\quad \square$ No

- your company's ability to "unlearn"- undoing the people, process, technology and knowledge that were once appropriate but are now holding your company back?
$\square$ Yes
$\square$ No

- your company's current focus and priorities?

$\square$ Yes $\square$ No

- your company's ability to react to sudden changes in the competitive environment?

$\square$ Yes $\square$ No

- your company's competitive intelligence and counter-intelligence ${ }^{*}$ processes and capabilities?

$\square$ Yes $\square$ No

* Competitive counter-intelligence capabilities can be defines as the ability to detect and neutralize external competitive intelligence actions targeting your own company. 
10. What is the number of new products introduced by your company since June 2001?

Answer:

11. What is the number of new processes introduced by your company since June 2001?

Answer:

12. What is the number of new services introduced by your company since June 2001 ?

Answer:

13. What is number of patents your company filed since June 2001 ?

Answer: 


\section{French version}

Information de veille concurrentielle et la performance en matière d'innovation chez les entreprises financées par le PARI

Étude effectuée par

Dr. Stoyan Tanev, stoyan.tanev@,vitesse.ca.

Tél.: (613) 746-3595, poste 228 , Téléc. : (613) 746-6653

Superviseur: Dr A. J. Bailetti, Dept. of System and Computer Engineering, Carleton University, Tony.Bailetti@sce.carleton.ca. Tél: (613) 520-2600, poste 8398

Cette enquête est réalisée dans le cadre d'une entente avec

le Programme de gestion de la technologie des télécommunications, Department of Systems and Computer Engineering, Université Carleton, Ottawa

le Programme d'aide à la recherche industrielle (PARI), CNRC l'Institut canadien de l'information scientifique et technique (ICIST), CNRC

Vitesse - réorientation professionnelle Canada inc.

Le présent questionnaire a été préparé aux fins d'un mémoire de recherche menant à l'obtention d'une maîtrise en génie en gestion de la technologie des télécommunications (GTT), au Department of Systems and Computer Engineering, Université Carleton, Ottawa. Ce mémoire a pour objectif d'examiner comment le type de compagnie et l'information concurrentielle utilisée afin de prendre des décisions quant à de nouveaux produits, procédés, services ou brevets affectent la performance en matière d'innovation chez les petites et moyennes entreprises financées par le Programme d'aide à la recherche industrielle du Conseil national de recherches du Canada (PARI-CNRC).

Il ne faut que 15 minutes pour répondre à ce questionnaire. Les informations demandées ne sont pas de nature délicate. Toutefois nous tenons à vous assurer l'anonymat des répondants et de leur entreprise sera strictement maintenue. Pour cette raison, nous vous invitons à nous envoyer ce questionnaire dûment rempli.

Vous pouvez répondre au questionnaire de manière électronique en utilisant le fichier Microsoft Word. Toutes les données que vous devez entrer sont sous forme numérique. Veuillez entrer les données dans les cases grises, par exemple : 4 . Pour répondre à certaines des questions, vous devez cocher 1'une des deux cases : « \ Oui » ou « \ Non $»$. Pour ce faire, vous pouvez cliquer sur la case que vous choisissez. Vous pouvez aussi imprimer le questionnaire, le remplir à la main et l'envoyer au CTI concerné par télécopieur.

Nous vous remercions du temps et de l'effort que vous consacrerez à la présente étude. Pour toute question, vous pouvez communiquer avec le Dr. Stoyan Tanev: Tél: (613) 746-3595, poste 228 .

Merci beaucoup pour votre collaboration. 


\section{DÉFINITIONS UTILES}

Nouveau produit. Pour les besoins de la présente recherche, un nouveau produit désigne un produit entièrement nouveau ou un produit ayant subi des améliorations importantes. Ainsi, un nouveau produit est un produit dont les caractéristiques technologiques ou les utilisations prévues diffèrent significativement de celles des produits précédents. Il peut mettre en cause des technologies radicalement nouvelles, peut être basé sur la combinaison de technologies existantes pour des usages nouveaux, ou peut être dérivé de l'utilisation de connaissances nouvelles. Exemples de produits nouveaux: Les premiers microprocesseurs et magnétoscopes à cassettes étaient des exemples de produits technologiquement nouveaux faisant appel à des technologies radicalement nouvelles. Le premier lecteur de cassettes portable, qui combinait les techniques existantes du ruban et du mini-écouteur, était un produit technologiquement nouveau combinant des technologies existantes pour un usage nouveau. Dans chaque cas, le produit global n'avait jamais existé auparavant.

Un produit amélioré est un produit existant dont la performance a été sensiblement améliorée ou haussée. Un simple produit peut être amélioré (en termes de performance améliorée et de coût plus bas) par l'utilisation de composantes ou de matériaux de performance supérieure, ou un produit complexe, consistant en un certain nombre de sous-systèmes techniques intégrés, peut être amélioré par l'apport de modifications partielles à l'un de ses sous-systèmes. Exemples de produits améliorés : Le remplacement de métal par du plastique dans les appareils électroménagers ou les meubles est un exemple d'utilisation de composantes de performance supérieure. L'arrivée du système de freinage antiblocage ou des améliorations à un autre sous-système automobile sont des exemples de modifications partielles à l'un des nombreux sous-systèmes techniques intégrés.

Nouveau procédé. Un nouveau procédé consiste en l'adoption de méthodes de production technologiquement nouvelles ou sensiblement améliorées, y compris les méthodes d'offre du produit. Ces méthodes peuvent comprendre des changements au niveau de l'équipement, ou de l'organisation de la production, ou une combinaison de ces changements, et elles peuvent être dérivées de l'utilisation de connaissances nouvelles. Les méthodes peuvent viser la production ou l'offre de produits technologiquement nouveaux ou améliorés, qui ne peuvent être produits ou offerts en utilisant des méthodes de production conventionnelles ou, essentiellement, pour accroître l'efficacité de la production ou de l'offre de produits existants.

Nouveau service. Un service est considéré comme étant un nouveau service lorsque ses caractéristiques et ses modalités d'utilisation sont complètement nouvelles ou qu'elles ont été sensiblement améliorées du point de vue qualitatif, ou en termes de performance et de technologies utilisées. La mise en place d'un service technologiquement nouveau peut exiger le recours à des technologies radicalement nouvelles, à une combinaison de technologies pré-existantes ou à des connaissances nouvelles. Un service consistant en un ensemble de sous-systèmes peut être technologiquement amélioré en changeant un ou plusieurs de ses sous-systèmes. Exemples de nouveaux services : Création de sites Web sur Internet, où de nouveaux services tels que de l'information sur un produit ou diverses fonctions de soutien peuvent être offerts gratuitement aux clients. La mise en service de cartes bancaires de plastique intelligentes et à usages multiples. 


\section{Veuillez répondre aux questions suivantes.}

1. En quelle année votre entreprise a t-elle été constituée en société (incorporée)?

Réponse :

2. Quel était le nombre approximatif d'employés de votre entreprise au cours des cinq dernières années?

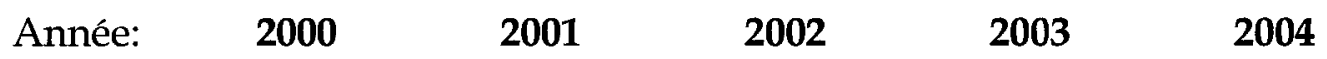

Employés :

3. Votre entreprise est-elle une entreprise de service? Veuillez cocher l'une des cases.

$\square$ Oui $\square$ Non

Si votre réponse est «Oui », veuillez passer directement à la question 6 . Si votre réponse est « Non », veuillez répondre à la question suivante.

4. Quelles sont les principales sources de technologie de votre entreprise? Veuillez ne cocher qu'une seule case.

Surtout externes $\quad \square$ Surtout internes

Si vous avez répondu « Surtout externes », veuillez passer à la page suivante et répondre aux questions s'y trouvant. Dans le cas contraire, veuillez répondre à la question suivante.

5. Sur quoi la technologie de votre entreprise est-elle basée? Veuillez cocher l'une des cases.

Surtout de la R-D interne et/ou l'appropriation des résultats de travaux de recherche scientifique universitaire.

Surtout de la conception technique à l'interne et/ou de la collaboration avec les principaux utilisateurs. 
6. Depuis juin 2001, votre compagnie a-t-elle pris des décisions au sujet de nouveaux produits, procédés, services ou brevets en se basant sur de l'information concernant:

- l'évolution, les changements en cours ou l'état futur de votre industrie?

Oui $\square$ Non

- des mesures de concurrence ou des actions/réactions particulières chez certains de vos concurrents existants?

$\square$ Oui $\square$ Non

- le marché/segment de marché de l'industrie dans toutes les interactions produitmarché?

$\square$ Oui $\square$ Non

- le pouvoir de négociation de vos fournisseurs ou des fournisseurs de vos concurrents?

$\square$ Oui $\square$ Non

- des menaces de l'apparition de nouveaux produits/services, y compris de technologies naissantes, qui pourraient affecter vos produits ou services actuels?

$\square$ Oui $\square$ Non

- la menace de l'apparition de nouveaux concurrents qui pourraient apporter des changements inattendus au niveau du marché/segment du marché actuel de votre industrie et de vos parts de la clientèle?

$\square$ Oui $\square$ Non

- le pouvoir de négociation de vos acheteurs ou des acheteurs de vos concurrents?

$\square$ Oui $\square$ Non

- des menaces de prise de contrôle ou de changements de régime de propriété chez des compagnies concurrentes ou associées qui pourraient obliger votre compagnie à prendre des mesures allant à l'encontre de ses intérêts à long terme?

$\square$ Oui $\square$ Non

- des menaces de mesures législatives, politiques ou sociales qui affaibliraient votre industrie ou qui lui attireraient une attention négative de la part de groupes d'intérêts spéciaux, de groupes politiques ou de groupes de pression et de critiques sociaux?

$\square$ Oui $\square$ Non

- des processus de mondialisation de la production, du marketing ou de la gestion relativement à votre industrie?

$\square$ Oui $\square$ Non 
7. Depuis juin 2001, votre entreprise a-t-elle pris des décisions au sujet de nouveaux produits, procédés, services ou brevets en se basant sur de l'information concernant:

- les compagnies et les clients qui sont les plus profitables pour votre entreprise?

$$
\square \text { Oui } \square \text { Non }
$$

- le potentiel de profit de votre entreprise provenant d'autres clients de l'industrie comparativement à vos clients existants?

$\square$ Oui $\square$ Non

- l'état actuel de vos relations avec les clients existants - la perception qu'ont vos clients existants de votre entreprise, de ses services, de ses ressources humaines et technologiques et autres capacités tant en termes absolus que relativement à vos concurrents?

$\square$ Oui $\square$ Non

- les principaux secteurs et initiatives où vos clients sont susceptibles de dépenser à l'avenir?

$\square$ Oui $\square$ Non

- votre portefeuille de clients actuels - la clientèle que votre entreprise ciblera, dans laquelle elle investira ou dont elle ne tiendra tout simplement pas compte?

$\square$ Oui $\square$ Non

- les positions de vos concurrents en ce qui a trait à vos clients existants?

$\square$ Oui $\square$ Non

- l'aptitude de vos clients les plus importants à entretenir des relations d'affaires avec d'autres firmes et, en particulier, avec votre entreprise?

$\square$ Oui $\square$ Non

- la nature de vos liens avec vos clients les plus importants - les principales valeurs qu'a pour eux le type de relations que votre entreprise entretient?

$\square$ Oui $\square$ Non

- le processus de prise de décisions de vos clients quant aux achats - les principaux critères sur lesquels repose l'évaluation que font des clients particuliers de votre entreprise et de vos concurrents?

$\square$ Oui $\square$ Non 
8. Depuis juin 2001, votre entreprise a-t-elle pris des décisions au sujet de nouveaux produits, procédés, services ou brevets en se basant sur de l'information concernant:

- l'historique et l'évolution de chacun de vos concurrents en ce qui a trait à la mission, aux objectifs et aux orientations stratégiques énoncés et manifestés?

$\square$ Oui $\square$ Non

- le profil général de chacun de vos concurrents?

$\square$ Oui $\square$ Non

- les forces et les pressions concurrentielles présentement exercées sur vos concurrents?

$\square$ Oui $\square$ Non

- les capacités distinctes de vos concurrents en ce qui a trait aux personnes, aux procédés, aux technologies, aux connaissances et à la veille à la concurrence?

$\square$ Oui $\square$ Non

- la dépendance de vos concurrents envers des comptes clés, des personnes clés, des clients, des fournisseurs, des régions et des institutions financières?

$\square$ Oui $\square$ Non

- la capacité d'innovation de vos concurrents en termes de capacité de produire de nouveaux produits, procédés, services et brevets?

$\square$ Oui $\square$ Non

- l'état des finances de vos concurrents, leur performance et leur potentiel actuels?

$\square$ Oui $\square$ Non

- la technologie de vos concurrents, y compris leurs capacités de R-D à l'interne, ainsi que leur capacité d'adopter des solutions technologiques de pointe provenant de l'extérieur?

$\square$ Oui $\quad \square$ Non

- la production de vos concurrents en termes de capacité et de qualité courantes et potentielles?

$\square$ Oui $\quad \square$ Non

- les capacités de marketing de vos concurrents?

$\square$ Oui $\square$ Non

- la force de vente de vos concurrents?

$\square$ Oui $\square$ Non 
9. Depuis juin 2001, votre entreprise a-t-elle pris des décisions au sujet de nouveaux produits, procédés, services ou brevets en se basant sur de l'information concernant:

- l'historique et les origines de votre entreprise?

$\square$ Oui $\square$ Non

- les réalisations maximales attendues de votre entreprise?
$\square$ Oui
$\square$ Non

- les capacités et les faiblesses distinctes de votre entreprise?

$\square$ Oui $\square$ Non

- le meilleur attrait qu'offre votre entreprise pour les clients comparativement à vos concurrents?

$\square$ Oui $\square$ Non

- la capacité de votre entreprise d'attirer les clients de vos concurrents?

$\square$ Oui $\square$ Non

- la capacité de votre entreprise de traiter avec ses clients difficiles?

$\square$ Oui $\square$ Non

- la capacité de votre entreprise à changer?

$\square$ Oui $\square$ Non

- la capacité de votre entreprise d'apprendre?

$\square$ Oui $\square$ Non

- la capacité de votre entreprise à " désapprendre »-se défaire des gens, des procédés, de la technologie et des connaissances qui ont déjà été appropriés mais qui l'empêchent maintenant d'aller de l'avant?

$\square$ Oui $\square$ Non

- les priorités et l'objectif actuels de votre entreprise?
$\square$ oui
$\square$ Non

- la capacité de votre compagnie à réagir aux changements soudains dans un environnement concurrentiel?

$\square$ Oui $\square$ Non

- les processus et les capacités de veille concurrentielle de votre entreprise ainsi que la capacité de réagir aux actions de veille concurrentielle de la part de vos concurrents?

$\square$ Oui $\square$ Non 
14. Quel est le nombre de nouveaux produits lancés par votre entreprise depuis juin 2001 ?

\section{Réponse:}

15. Quel est le nombre de nouveaux procédés lancés par votre entreprise depuis juin $2001 ?$

Réponse:

16. Quel est le nombre de nouveaux services lancés par votre entreprise depuis juin $2001 ?$

Réponse:

17. Quel est le nombre de demandes de brevets déposées par votre entreprise depuis juin 2001 ?

Réponse: 